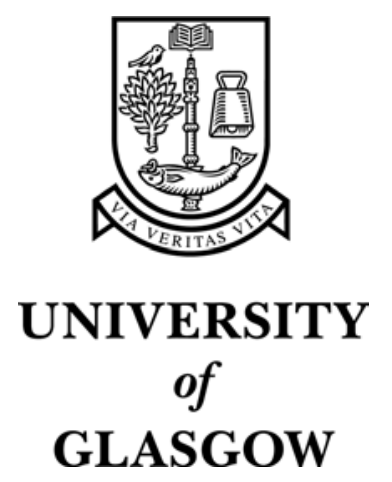

Beattie, V. and Goodacre, A. (2004) Publishing patterns within the UK accounting and finance academic community. The British Accounting Review 36(1):7-44.

http://eprints.gla.ac.uk/archive/00000769/ 


\title{
Publishing Patterns within the UK Accounting and Finance Academic Community
}

\author{
Vivien Beattie and Alan Goodacre
}

University of Stirling

Correspondence details

Professor Vivien Beattie

Department of Accounting, Finance and Law

University of Stirling

Stirling

FK9 4LA

Tel. 01786467306

Fax. 01786467308

Email V.A.Beattie@stirling.ac.uk

\section{Acknowledgements}

The authors would like to thank the Faculty of Management, University of Stirling, for awarding us a research grant to fund this project. We are grateful to Joanne Lello in particular for her assistance with data collection. Special thanks go to Elizabeth Davie for her advice and assistance in designing the Access database. 


\title{
Publishing Patterns within the UK Accounting and Finance Academic Community
}

\begin{abstract}
This study reports on publishing patterns in the UK and Irish accounting and finance academic community for the two-year period 1998 to 1999 using the data contained in the BAR Research Register. It is found that the community has been growing modestly since 1991, with a doubling in the number of PhD-qualified staff (to 30\%) and a reduction in the number with a professional qualification (from $81 \%$ to $58 \%$ ). Nearly half of all outputs appear in other than academic journals. The mean number of publications is 1.76 per capita, with significantly more staff active in publishing than in 1991 (44\% compared to 35\%). However, only 17\% publish in a subset of 60 'top' journals. Just over half of all articles are published in the core discipline journals, the rest appearing mainly in management, economics, sociology, education and IT journals. This may indicate a growing maturity in the disciplines, whereby applied research findings are flowing back into related foundation and business disciplines. Nearly two-thirds of academic articles are co-authored, with $25 \%$ of contributions coming from outside the community, indicating an openness to interdisciplinary collaboration, collaboration with overseas academics and collaboration with individuals in practice. The findings of this study will be of assistance to those making career decisions (either their own career or decisions involving other people's careers). They also raise awareness of the way in which the accounting and finance disciplines are developing.
\end{abstract}

Keywords: co-authorship; journals; non-serial publications; publication media; scholarly knowledge development 


\section{Publishing Patterns within the UK Accounting and Finance Academic Community}

\section{INTRODUCTION}

Academics in all disciplines are interested in the publication records of their peers, whether at the country, department or individual level of analysis. There are two main reasons for this, apart from natural curiosity. First, as academics we have to make decisions that are based, in part, on an assessment of research output. These may be decisions about our own career, such as which jobs to apply for and when to seek promotion (Read, Rama \& Raghunandan, 1998; Tompkins, Hermanson \& Hermanson, 1996). Alternatively, we may be in the position of making decisions about the career of others, in our role on appointment panels and advancement committees and as external assessors, or of judging whether probationary hurdles have been passed (Hasselback \& Reinstein, 1995; Zivney, Bertin \& Gavin, 1995; Zivney \& Bertin, 1992). Second, the analysis of publication patterns can contribute to our understanding of the cognitive and social aspects of scholarly knowledge development. 'Disciplinary self-awareness' of this form is viewed as a sign of a discipline’s maturity (Borgman, 1990).

In the disciplines of accounting and finance, there are a growing number of studies of publication records. Most studies relate to the US, but there are also studies covering the UK, Australia, New Zealand and, most recently, continental Europe (Lukka \& Kasanen, 1996). Most studies focus exclusively on academic journal articles, thus excluding professional journal articles and non-serial publications such as books and research reports. Moreover, most studies focus on publications in a restricted set of journals within the discipline. Given the growing evidence of the existence of research élites who control the 'top' journals (Lee, 1995, 1997; Williams \& Rodgers, 1995), it is of critical importance not to restrict studies to a small 'self-referential closed set' of élite journals (Lee \& Williams, 1999, p.870). Raw counts are often transformed into 'quality'-adjusted measures based on journal rankings. Many studies report only on the more prolific authors and the most productive departments, omitting details about the entire distribution of performance, and thus presenting a 'limited and fragmented' view of publishing activity (Zivney et al., 1995, p.1). Of course, given that the distribution is very skewed, it is of interest to report on the level 
of concentration of publication activity across the distribution (Hasselback \& Reinstein, 1995).

The US literature treats the quantitative 'quality-adjusted' rankings so produced as essentially objective and entirely unproblematic, consistent with the positivist, scientist tradition of research in the US. In the UK and elsewhere, however, there has always been an awareness that such data may be used for political ends and the need for a sensitive treatment of the data if unintended consequences are to be avoided (e.g. Hutchinson, 1989). In the last decade, several writers have offered critical discussions that point to the 'commodification' of academic labour and the apparent desire of government and institutions to 'control' and 'manage' scholarly activity (e.g. Puxty, Sikka \& Willmott, 1994; Willmott, 1995; Parker, Guthrie \& Gray, 1998; Gray, Guthrie \& Parker, 2002). These authors express concern that information about publication records is a double-edged sword - while the information is valuable to academics, it can also be used against us.

The purpose of the present paper is to contribute to our knowledge of publishing patterns by UK and Irish accounting and finance academics at the community level. The results reported are based on the data contained in the British Accounting Review Research Register 2000, (hereafter the Register) the most recent edition of this biennial publication available at the time this study was conducted (Helliar \& Gray, 2001). This publication covers both the accounting and finance disciplines because they are closely related and are usually located within the same organisational unit within institutions. This publication includes all the self-reported publications of 1,508 staff in the UK and Ireland across 110 institutions.

The paper reports on (i) community demographics; (ii) the distribution of outputs across all publication media; (iii) the distribution of professional journal articles across specific outlets; (iv) the distribution of academic journal articles across specific outlets; (v) the distribution of academic journal articles across disciplines; and (vi) the incidence of co-authorship. In reporting on the distribution of outputs across all publication media, separate analysis will be presented for key subgroups (viz. institution type, academic rank and faculty qualifications). ${ }^{1}$ 
The remainder of this paper is structured as follows. Section two briefly reviews five diverse strands of relevant literature, relating to the value of alternative publication forms, the heterogeneous value ascribed to academic journal articles, prior empirical studies of community-level publication records, interdisciplinary influences and coauthorship. The third section sets out our methods, in particular it describes how the database was constructed from the Register as initial data source. Results are presented and discussed in section four. A final section summarises and concludes.

\section{PRIOR LITERATURE}

In this section we review five diverse strands of relevant literature. First, to provide a context in which to interpret the empirical findings of the study, this includes a discussion of the role, intrinsic value and extrinsic value of different forms of publication. Second, the extrinsic value of academic journal articles, while generally high relative to other publication forms, is generally viewed as being highly variable, depending on the 'quality' of the journal. The methods and findings of such studies are reviewed. Third, we review the prior literature regarding aggregate and average publication output, both empirical studies and commentaries. Fourth, we consider the limited findings regarding interdisciplinary influences. Finally, we review the literature on co-authorship.

Before embarking on this review of the literature, however, it is worth setting publication activity in the general context of scholarly activity, which also includes teaching and service (both internal and external to the institution) (Gray et al., 2002). It follows that a focus on publication output provides a partial view of scholarly contribution. There is evidence, however, that publication is, and is seen to be, the major (and growing) element in the assessment of academics. For example, the qualitative evidence presented by Parker et al. (1998, pp.381-383) from interviews with 40 senior academics in the UK and Australia supports this view.

\section{Relative importance of publication media}

There is general recognition of the important role played by publications other than academic journal articles in the dissemination of knowledge to fellow academics, students, the profession and the business world. However the extrinsic value placed 
on such outputs does not appear to reflect this intrinsic value. For example, Parker et al. (1998) report a major shift in the weightings used by the Australian Federal Government's Department of Employment, Education and Training (DEET) in undertaking quality reviews. While the 1996 weightings covered a comprehensive range of publication media, the list was pruned in 1997 to include only four media: research books, articles in scholarly refereed journals, chapters in research books and refereed conference proceedings.

Parker et al. asked senior academics about the 'significance and desirability' of seven media. Overall, these were ranked (in descending order) as follows: refereed research journal articles, research monographs, research books, textbooks, chapters in books, refereed conference papers, and edited books and professional journal articles (1998, pp.379-380). They also find evidence of a 'quantity plus quality' evaluation rule being applied by many gatekeepers. ${ }^{2}$

It is noticeable that in these weightings (both official government weightings and the informal weightings of senior academics), textbooks (which act as a bridge from research to teaching) and professional journal articles (which act as a bridge from the academic community to practice) no longer feature. In the UK, there is no indication that professional publications were valued from an RAE perspective. The gap (or schism) between research and practice has been a concern for several decades (Baxter, 1988). Zeff \& Hofstedt (1974) argue that the gap can be attributed to a failure by academics to communicate. In this case, there exists the possibility of closing the gap. Bricker \& Previts (1990) claim that the shift by the academic community toward a social science model of research and the growing differences in the educational credentials of the two communities are to blame. Yet others argue that the gap is inevitable, as practice will always resist basic research that carries with it the potential for upsetting the status quo (Lee, 1989).

\section{Academic journal ranking studies}

Given the pre-eminent position of academic journal articles, it is not surprising that academics have devoted a great deal of effort towards the creation of journal rankings. Three main approaches have emerged: citation studies, perception studies and, most recently, 'market-test' studies. In all cases, the number of journals ranked varies 
enormously (and has increased over time as the number of journals has increased). Each of the approaches has limitations.

Many citation studies make use of the Social Sciences Citation Index (SSCI). The basic idea is that a citation is an objective indicator of influence. The number of accounting and finance journals covered by this index is, however, limited, with many major outlets (for UK academics) not included. The most recent study in the finance discipline is Chan, Fok \& Pan (2000) who rank 59 journals using the SSCI.

Perception (or peer-review or opinion survey) studies appear to have been the dominant approach used in the accounting discipline. Typically, respondents are asked to assign points to each journal, based on its 'value', 'familiarity' and/or 'quality'. The only recent UK study evaluates 44 accounting and finance journals (Brinn, Jones \& Pendlebury, 1996).

The market-test is based on an analysis of library holdings. Bertin, Prather \& Zivney (1994) rank 62 journals using the holdings of 264 schools. Zeff (1996) reports on subscriptions to 67 accounting journals by twelve major libraries (located in the US, the UK and Australia), identifying three modal groups across the grading of journals. These gradings are interpreted as quality rankings by Wilkinson \& Durden (1998) and Durden, Wilkinson \& Wilkinson (1999) and used by them to construct weighted measures of productivity of accounting faculty in New Zealand and Australia, respectively. Locke \& Lowe (2002) replicate Zeff's analysis for all 46 universities in Australia and New Zealand, with the intention of constructing a set of journal rankings of relevance to authors from that region. They find a 'good deal of disparity' in the two sets of journal gradings.

While many journal ranking studies appear content to treat the measures obtained (using any approach) unproblematically as interval level measures, some writers have chosen instead to classify the measures into broad ordinal categories. Gray \& Helliar (1994) establish two journal groups - premier and secondary. Premier journals (of which there are 40) are those that are always refereed. Secondary journals (of which there are 39) are those that are predominantly academic but not always refereed or where the refereeing policy is unclear. Brown \& Huefner (1994), in a perceptions 
study of 44 accounting journals using US respondents, refer to 'three thresholds of quality'. Zeff (1996) identifies three modal groupings from his market test study. Hickman \& Shrader (2000) create three quality groupings out of the 71 finance journals listed in Heck's Finance Literature Index, making use of Alexander \& Mabry's (1994) citation-based quality ratings. Hasselback, Reinstein \& Schwan (2000) create four groups in their study of productivity benchmarks for accounting faculty by using cluster analysis: the best 4 , the best 12, the best 22 and the best 40 . This ordinal grouping approach has the advantage of not suggesting spurious accuracy in the ranking measures although inevitably a boundary problem exists for a few journals at the margins.

\section{Empirical studies of community-level publication records}

In the UK, Gray \& Helliar (1994) report on the publication record of the entire population of 1371 accounting and finance academics for the two-year period 1990 to 1991. In addition to reporting demographic data, they report statistics for the percentage of faculty having at least one publication in a comprehensive range of publication media (reported in the results section of the present paper to enable comparison to be made across time). Overall, $62 \%$ of 'old' university faculty have at least one publication of any form, compared to $14 \%$ of 'new' university faculty. ${ }^{3}$ They also report the average publication per head of those who do publish in the different media, with old university faculty publishing more frequently in certain media (premier journals; chapters; conference proceedings and other publications).

Gee \& Gray (1989) analyse publication outputs by departments (before the abolition of the binary divide) using the 1986 and 1988 Registers and eight different criteria. They argue that to make valid trans-binary comparisons, there should be recognition of a 'dilution' effect, due to polytechnic staff not involved with degree-level work and therefore not necessarily involved in research and publication. For this reason, they propose using 'output per capita of publishing staff' as a more equitable measure. In a response to this study, Hutchinson (1989) notes the difficulties in making valid comparisons across the two sectors. He observes that the notion of research in the polytechnic sector is broad, including consultancy, technical matters and pedagogic issues, activities which may not lead to publication. He also notes the lower funding levels per FTE student, which may result in higher teaching loads and less support 
staff and other facilities, thereby reducing the time available to produce published outputs. Despite the abolition of the binary divide, comparisons between the old and new university sectors are influenced by the carry-over effect of lower levels of funding and continuing differences in the mix of courses taught.

Studies in other countries tend to focus exclusively on publications in a set of core journals, usually only accounting and finance journals. In the US, Zivney et al. (1995) report on the publication record of nearly 5,000 doctorally qualified accounting faculty (virtually the entire population) over a 28-year period (1963-1990). By reporting data on the entire distribution of faculty publications they claim to offer a 'comprehensive' examination, however they focus on a restricted set of 66 established journals. The journals are those included in Heck's Finance-Accounting Literature Database. These are divided into two groups - academic accounting journals and other journals (finance journals and practitioner-oriented journals). It is found that the average number of publications over this period is 4.4 articles, which represents 0.16 articles per year. 50\% of faculty publish at least one article over their career, $40 \%$ publish at least one academic accounting article and $23 \%$ publish at least one article in the top three journals (TAR, JAR and $J A E){ }^{4}$

Hasselback, Reinstein \& Schwan (2000) report on the publication record of nearly 4,000 accounting faculty with accounting doctorates earned between 1971 and 1993 (a 23-year period). They focus on a restricted set of 40 accounting journals. They find that $39 \%$ of the group had not published any articles in the journal set with $9 \%$ publishing more than 9 articles. The latter figure falls to $3 \%$ if an adjustment is made for joint authorship.

In New Zealand, Wilkinson \& Durden (1998) report on the publication record of 101 faculty at seven universities over a six-year period (1992-1997). Publication data is obtained from two literature indexes and directly from Australian and New Zealand journals. The latter source was used to construct a journal set appropriate to New Zealand academics. While their analysis is restricted to journal articles, they do include at least some non-accounting journals (specifically those indexed in $A B I$ Inform). Among the measures reported are the total unweighted number of journal articles per annum per capita $(0.37$, derived from Table 7, p.87) and the total 
unweighted number of professional journal articles per annum per capita $(0.18$, derived from Table 9, p.88).

Durden, Wilkinson \& Wilkinson (1999) essentially replicate Wilkinson \& Durden (1998) for the Australian academic community. They identify 57 distinct campuses across 36 universities. In this study it is not, however, possible to deduce the total number of faculty for all institutions and thereby calculate overall average publication measures.

\section{Interdisciplinary influence}

It is well known that the level of interdisciplinary borrowing (in relation both to theories and analytical methods) is relatively high in the disciplines of accounting and finance. Patterns of this nature are most commonly studied using citation analysis. Cox, Hamelman \& Wilcox (1976) undertake an early citational analysis of the business literature (defined to include 38 journals in the disciplines of accounting, economics, general business, finance, management and marketing but reduced to 19 journals in the final analysis due to data limitations). They identify two main clusters - economics and functional applications of existing theory/business. It is argued that the relational characteristics of journals can reveal important clues about the development of disciplines. It may be noted that when all five initial accounting journals are eliminated, the Journal of Finance is located closest to the economics cluster. Longitudinal analysis would reveal emergent or dissolved interdisciplinary linkages.

McRae (1974) used citation analysis to examine the flow of messages between the accounting knowledge system and other knowledge systems and within the accounting knowledge system itself. The accounting knowledge system is viewed as nesting within the social science knowledge system. It is composed of (at least) three sub-systems: academic accounting, and applied accounting, the latter being composed of 'business' and 'professional'. Citations in 17 accounting journals (academic and professional) for the two years 1968-1969 are collected and classified into systems, thus the focus is on the degree of influence from other systems to academic accounting. For the academic journals only, 67\% of citations were within the accounting knowledge system, 27\% were to other social science knowledge systems 
and $6 \%$ were to other knowledge systems. The distribution of citations to nonaccounting journals was as follows: $56 \%$ to business (including finance and tax); $18 \%$ to economics; $7 \%$ to mathematics and statistics; $5 \%$ to law; $4 \%$ each to psychology and engineering; $3 \%$ to history; $1 \%$ to sociology/politics and $2 \%$ other. The flow in the other direction was found to be negligible - only 2 out of over 5,000 citations in four mainstream journals in economics, psychology, sociology and politics and three interdisciplinary journals were to accounting journals.

McRae, Letza \& Sim (1993) repeat this analysis for the two years 1987 and 1988, i.e. almost 20 years later. A somewhat different journal set is used, given the emergence of new journals. In this latter study, $A O S, A B R, B A R$ and $J B F A$ are included. ${ }^{5}$ There are 11 academic journals and 14 professional journals. They conclude that the academic and professional networks are drawing further apart and there has been a huge increase in the citation of journals outside the accounting network.

While McRae (1974) specifically excludes book citations, the focus of Beattie \& Ryan's (1991) study is to examine the influence of other disciplines by categorising into foundation disciplines the citations to non-serial publications (specifically books) appearing in thirteen leading journals. Book citations are found to account for $18 \%$ of all citations, made up as follows: accounting $-21 \%$; economics and finance $-26 \%$; sociology/political science $-20 \%$; statistics $-12 \%$; management $-11 \%$; psychology $5 \%$; others $-5 \%$.

It appears, therefore, to be generally assumed that disciplinary links (certainly for accounting) operate only in one direction (there are minimal citations to accounting from journals outside the core disciplines. Thus, there seems to be no real knowledge feedback loop from the application discipline back to the source discipline. The present paper examines the relative incidence of publishing outside the core disciplines (rather than the relative incidence of citation to accounting and finance journals from journals outside the discipline. Of course, the fact of publishing outside the core discipline is a necessary, but not sufficient condition, for accounting and finance to influence these other disciplines. However the existence of significant 'outside' publishing activity could be a sign of the maturing of very 'young' disciplines (This assumes that the individuals in the Register all view accounting as 
their 'home' discipline). The studies applying concepts and methods from these outside disciplines have become of sufficient quality to merit recognition in the journals of the foundation discipline.

\section{Co-authorship}

Mullins (1973) identifies four types of social relationship that can exist between scholars: co-authorship; trusted assessorship; colleagueship; and apprenticeship. Coauthorship involves an extremely close association where two or more scholars engage in collaborative research. Heck, Jensen \& Cooley (1990) present evidence of a marked increase in co-authorships in 24 accounting journals ${ }^{6}$ for the decade 1979-1988. They also report that the proportion of articles co-authored has risen from $3 \%$ in 1952, to $10 \%$ in $1962,26 \%$ in $1972,40 \%$ in 1982 and $50 \%$ in 1988 . They identify three possible reasons for this: increases in professor/doctoral student joint authorship; large-team research efforts; and 'publish or perish' pressures, whereby two joint authorships are preferred to one solo effort. Hasselback et al. (2000) examine a set of 40 accounting journals and report that the average number of authors per article has grown from 1.86 in 1971 to 2.30 in 1993, a rate of 0.017 authors p.a. (p.95).

It is now relatively common for studies of publication output to make an adjustment for joint authorship based on the principle of indifference (Beattie \& Ryan, 1989), allowing fractional credit based upon the number of authors. Whilst some form of adjustment seems appropriate, given the evidence that some institutions don't give full credit for co-authored publications (Hasselback et al., 2000, p.84), survey evidence shows that the credit given is more than proportionate (Schinski, Kugler \& Wick, 1998). Most studies tend to adopt one or other option, however Hasselback \& Reinstein (1995) and Hasselback et al. (2000) report both bases. Neither of these studies formally investigates whether the co-authorship adjustment makes a significant impact on rankings. Interestingly, Heck et al. (1990) report that the Pearson correlation coefficient between adjusted and unadjusted number of publications for all contributors to the 7,827 articles in their dataset was 0.861 .

In summary, the prior literature indicates that certain tensions exist with regard to the value placed on various types of publication. In particular, increased weighting is being (or is being seen to be) given to academic journal articles in some countries. 
Given the financial consequences of these weightings at both the micro (personal) and macro (institutional) levels, there is a danger of instrumental behaviour. This emphasis on academic journal articles has resulted in great interest in assessing the 'quality' of different journals, using a range of methods. While there is a good level of consensus across methods and countries, the journal set evaluated and the rankings must be relevant to the geographic location of the community of interest. There is a growing tendency to use such rankings conservatively by forming broad quality groupings.

The main prior study of publication patterns by the UK academic community was undertaken by Gray \& Helliar (1994). In addition to updating aspects of their study, the present study addresses two further issues argued by the prior literature to be of considerable significance in understanding the cognitive and social aspects of scholarly knowledge development. These are the extent and nature of interdisciplinary information flows and the extent of co-authorship.

\section{METHODS}

\section{The data-source}

The Register collects, via a survey of all institutions, details of the publications during 1998 and 1999 of accounting and finance faculty in post at $31^{\text {st }}$ December $1999 .^{7}$ Knowledge that the register is widely used by academics provides strong incentives on both individuals and institutions to ensure completeness. The definition of 'publication' used excludes working papers, unpublished conference papers, in-house publications, private reports, and forthcoming publications. The Register's convention is to list only once those publications co-authored by individuals at the same institution. However, where an item is co-authored by accounting and finance faculty at different institutions, the item will be cited two or more times. This somewhat unbalanced treatment means that to ensure that the publication record of the community as a whole is not overstated, items involving inter-institutional coauthorship need to be identified and eliminated. By contrast, where we report measures requiring the attribution of credit to institutions or individuals (such as measures by institution type of on a per capita basis) we give full credit to each author. 


\section{The database}

We designed the database so that it would not only support a rigorous analysis of publications at the community, institutional and individual levels, but would permit an analysis of certain social aspects of publishing activity (co-authorship behaviour, promotion requirements and gender issues). (These latter issues will be reported in detail in subsequent papers.)

Consequently, we set up a relational database, using Microsoft Access. The two principal data tables are the staff table and the publications table. The staff table included 7 fields relating to the 2000 edition of the Register. Aspects of background experience and training are captured by recording whether individuals have a professional qualification and whether they have a Ph.D. The staff table has two supporting tables: institution and position. We now discuss each briefly.

In our paper, details are presented for 108 institutions, rather than the 110 in the Register. As in the Register, the database maintains separate entries for Edinburgh University's 'Accounting and Business Method' and 'Business Studies' departments. However we chose to combine Nottingham Trent University's departments of 'Accounting' and 'Finance'. Both choices were made to maintain consistency with prior registers. Bath University is omitted as no details of publications are provided. The number of individuals is 1,492, 16 less than the 1,508 stated in the Register. This difference is primarily due to individuals included in the names index at the back of the Register for whom there is no individual entry in the body of the Register. ${ }^{8}$

We recorded in the database 27 different position titles (i.e. academic ranks). These included common UK titles, as well as US titles, research-only titles and teachingonly titles. In most of the results that follow, these are grouped into a smaller number of categories. ${ }^{9}$

The other principal data table, the publications table, is linked via the author identifier to the staff table. The publications table captures authorship details as well as recording the type of publication (pub-type). This latter field has a supporting table. We draw a fundamental distinction between serial and non-serial publications. The 
title of all serial publications was recorded. We included the 64 publications listed in the Appendix to the Register, which relate to individuals in transit during the period. In subsequent analysis, serial publications were further divided into academic and professional (a catch-all term for non-academic serial publications that includes newsletters, magazines and newspaper articles). ${ }^{10}$

\section{Classification of journals by discipline}

In developing a set of decision rules to classify academic journals into disciplines we adapted the foundation disciplines used by Brown, Gardner \& Vasarhelyi (1987) and Beattie \& Ryan (1991) and the criteria for identifying accounting journals used by Zeff (1996). The general thrust of the decision rules was to broadly circumscribe the accounting and finance discipline. The aim was to include all journals that accounting/finance faculty might reasonably be expected to publish in.

Consequently, in dealing with journals at the interface of two disciplines, different rules were applied depending on whether the interface involved either accounting or finance. If it did, then the journal was treated as either accounting or finance. If it didn't, then the classification was made on the basis of fundamental discipline rather than area of application. Interface journals that lie wholly outside accounting and finance and with no apparent application perspective (often signalled by the word 'and') were allocated equally to their respective disciplines. A full explanation of the decision rules adopted together with examples is given in Appendix 1.

Once the criteria had been agreed, both researchers categorised all of the journals independently. Differences in classification were identified (8.6\% - see Appendix 1 for details of their nature). There were discussed and, where necessary, resolved by reference to the categorisation in Ulrichs (2001).

\section{RESULTS}

\section{Community demographics}

By the end of 1999, the size of the community had grown to 1,492 individuals (up from $1,371^{11}$ at the end of 1991). This represents a growth of $9 \%$ in 8 years. These individuals are employed across 108 institutions, of which 59 are 'old' universities 
and 49 are 'new'. The mean size of departments in the new universities is significantly larger than the old universities, with a mean staff complement of 16.8 compared to 11.3, respectively. The corresponding figures for 1986-87 based on 79 institutions were 15.3 and 8.6 (Gee \& Gray, 1989, p.49). This suggests that the size gap is shrinking as the size of old universities increases.

A detailed breakdown of the population by type of institution, academic rank, and qualifications (including comparisons with Gray \& Helliar (1994) where possible) is given in Table 1. Since 1991, there has been a general increase in the seniority of faculty at the old universities, with the distribution at the new universities remaining very stable. Across the combined set of institutions, the proportion of faculty with PhDs has doubled (from $16 \%$ to $30 \%$ ), while the proportion with a professional qualification has declined significantly (from $81 \%$ to $58 \%$ ). It is noticeable that the proportion of faculty with a $\mathrm{PhD}$ increases with rank while possession of a professional qualification seems to be unassociated with rank.

[Table 1 about here]

\section{Distribution of outputs across all publication media}

To establish the total output of the UK accounting and finance community for the two-year period 1998/99 across all forms of publication it is critical to exclude multiple entries, as discussed above. This gives a figure of 2,178 outputs. ${ }^{12}$ The distribution of these outputs across publication media is shown in Table 2.

[Table 2 about here]

It is interesting (and arguably comforting) to note that, despite the pre-eminent position that academic journals are widely believed to hold, nearly half of all outputs are in other media, principally professional journals and books. Research reports (at $3.5 \%$ of total) fall a long way behind.

Table 3 presents per capita data publication measures for different sub-groups within the community. The primary distinction made is between faculty at old and new universities. These two sub-groups are then further partitioned by academic rank and 
by faculty qualification. Full credit is given for co-authored publications, giving a total of 2,629 attributed publications. ${ }^{13}$ The original set of publication media is reduced to three categories in this table: academic journal articles, professional journal articles and non-serial items (a category formed by combining all non-serial media).

Academic journal articles are split out into three categories: Top30 $A \& F$ (being the top 30 ranked accounting and finance journals in Brinn et al. (1996)), Top30 Oth (being the top journals from other relevant disciplines, based on an evaluation of the many rankings reported in Harzing (2001)); and Non-top60 (being all other academic journal articles). The second of these categories was formed because of the extent of non-core discipline journal publishing by the community. Combining the first two of these categories forms a derivative category of Top60. A full list of the journals included is given in Appendix 2. We chose to use broad two-tier groups of journals because of the difficulties associated with journal rankings. We also chose to base this grouping on the perceptions of UK faculty, since it is the publications of UK faculty that are being categorised and perceptions studies have been shown to be sensitive to the geographic location of respondents.

\section{[Table 3 about here]}

Table 3 shows that the mean number of publications by the community during 1998 and 1999 was 1.76. Faculty in the old universities produce, on average, nearly three times as many items as those in the new universities. As one would expect, given the significance of research in promotion decisions, there is a strong positive correlation between academic rank and number of publications and this applies across all publication media. Possession of a $\mathrm{PhD}$ is strongly associated with academic journal outputs and non-serial outputs, but does not seem to affect the number of professional journal outputs. Possession of a professional qualification seems to increase the numbers of professional outputs (but only in the old university sector). If fractional rather than full credit is given for co-authored publications, the overall patterns remain essentially unchanged, although the reported means all drop significantly. For example, the overall mean falls from 1.76 to 1.09 , because some co-authors are outside the UK accounting and finance academic community. 
Due to the differences in the nature of the data available, only crude comparisons are possible with other countries. It is, however, interesting to observe that Zivney et al. (1995) report an average number of publications in a set of 66 accounting and finance journals of 0.16 p.a. In the present study, using a set of 30 journals, the figure is 0.12 . Given the difference in the size of the journal set, the publication activity (i.e. quantity of output) of UK academics appears to compare very favourably to that of US academics.

While Table 3 presents mean per capita measures for particular groups, it is also important to examine the overall distribution, particularly as publication activity is known to be skewed. The distributions for selected academic ranks within each institution type can most effectively be shown graphically. Figure 1 shows the percentage of faculty that have at least a given number of publications. Panels $\mathrm{A}$ to $\mathrm{C}$ refer to three different output categories: all publications, all academic journals and Top60, respectively. Given that publication activity is strongly linked to academic rank, we plot only the upper and lower ranks in each institution type, along with the Senior Lecturer (old universities) rank as an 'average'. The SL and L profiles in the new universities are very similar. Table 4 presents this information in tabular format.

[Figure 1 and Table 4 about here]

Table 4 panel A shows that, overall, 56\% of staff published nothing during the twoyear period. This is down from 65\% in 1991 (Gray \& Helliar, 1994, derived from Table 3). The figures for old and new universities are $31 \%$ and $76 \%$, respectively, in 1999, down from $38 \%$ and $86 \%$ in 1991 . Panel A of Figure 1 plots the corresponding frequency distribution. ${ }^{14}$ Professors at the new universities are seen to outperform professors at the old universities in terms of the total number of publications. There are significant gaps between the curves for the various groups shown, with the lecturer curves being particularly concave, reflecting the extremely skewed nature of their distribution.

Panel B of Table 4 and Figure 1 refer to the academic journal subset of all publications. The percentage of staff publishing no academic articles in the period is 
$65 \%$ overall. This comprises $41 \%$ for old universities and $84 \%$ for new universities, with the corresponding figures for 1991 being 63\% and 98\% (Gray \& Helliar, 1994). Once again, there is evidence of a significant increase in the proportion of staff actively publishing in academic journals. Looking at Figure 1, panel B, the difference in relative performance of professors from the old and new institutions is seen to be less than in panel A. The distributions are very similar up to 3 publications but, thereafter, professors in the new universities continue to be more productive.

Panel $\mathrm{C}$ of Table 4 and Figure 1 refer to the Top60 subset of academic journals. The distributions are shown at a finer level of detail than Panels A and B, and are curtailed at 6 articles as no-one in the community exceeded 6 publications in this subset. $83 \%$ of all staff published no Top60 articles in the period. It is noticeable that at the new universities only professors generally publish in these journals. The curves in Figure 1 show that the publishing profiles of new university professors and old university senior lecturers are very similar. This may reflect the fact that professors at new universities are often recruited from the senior lecturer rank at the old universities. While $15 \%$ of all professors manage to publish 6 or more academic journal articles, only $1 \%$ manage to publish 6 or more in the Top60. In other words, only two professors manage to publish in the leading journals at this level of frequency; a further three published 5 Top60 papers.

Panel D of Table 4 provides details for the Top30 A\&F subset of academic journals and shows a similar pattern to the Top60 results. Again, it highlights the difficulty of achieving high quality output with just $13 \%$ of professors publishing more than one Top30 A\&F paper per year.

\section{Distribution of professional journal articles across specific outlets}

The 355 distinct professional articles were spread across 92 different outlets. A full listing, classified by discipline and showing the number of items in each outlet, is given in Appendix 3. This is provided to help authors identify potential outlets for their work. $84 \%$ of all items appear in accounting and finance outlets. The most common outlet, Management Accounting, takes twice as many articles as its nearest rivals, Accountancy and Student Accountant. 
Our findings in relation to professional journals can be compared to the results in Cottingham \& Hussey (2000), who look at publications in five main professional accounting journals during the period 1987-96. They report on the number of UK academic authored articles in the house journals of the five main accountancy bodies. The reported figure for 1996 is 68 articles. If we select only these journals, our figure for the two-year period 1998-99 is 99, yielding a yearly average of 50. It appears, therefore, that in the space of only 2-3 years, there has been a substantial decline in publications by UK academics in this professional journal set. Looking at the trend since 1987 (when the figure was 90), there is evidence that this is a continuing and accelerating decline. There are, of course, several possible reasons for this observed decline. While it may be that academics are less inclined to seek publication in such journals, it may also be that the journals themselves are less disposed to accept academic articles. There has certainly been a marked shift in the editorial policy of some journals, showing a preference for very short commentary and lifestyle articles.

Having said this, however, it must be noted that publications in this subset of professional outlets represent only $28 \%$ of all professional publications, which (as reported above) represent a significant proportion of all publications.

Distribution of academic journal articles across specific outlets and across disciplines

The 1,141 distinct academic articles were spread across a staggering 442 different outlets (this should bring comfort to those unable to think where to target their next publication!). A full listing, classified by discipline and showing the number of items in each outlet, is given in Appendix 4. This is provided to help authors identify potential outlets for their work. The contents of this Appendix make for interesting reading.

In the discipline of accounting (taken to include taxation), there are 423.5 papers spread across 61 journals. None of the top ten journals (in terms of publication frequency) is clearly US based - eight are $\mathrm{UK}^{15}$, one is continental Europe and one is Australian. While there are 16 publications (ranking $11^{\text {th }}$ in terms of frequency) in $A O S$, normally rated as one of the top four in terms of 'quality', there are no publications in any of the other top three journals (TAR, JAR and JAE), all of which 
are US-based. There is only one publication in Contemporary Accounting Research (a Canadian journal normally rated just below these US journals and AOS in terms of quality). At least three, not necessarily mutually exclusive, interpretations of these findings are possible. First, it may be accepted that these North American journals do indeed represent the highest quality journals worldwide and that UK academics are generally unable to publish at this highest level. However, the pre-eminent quality often attributed to these journals is contested by some. Second, the findings are consistent with the high barriers to entry that are perceived by UK academics to exist for non-US faculty seeking to publish in this top set of US journals (Brinn, Jones \& Pendlebury, 2001). Finally, the findings could be interpreted as offering strong support for the thesis of Lukka \& Kasanen (1996), that accounting is a local rather than a global discipline.

In terms of sub-areas, certain journals clearly cater for particular areas while others are very general in nature. A fairly crude categorisation based on journal title suggests that about $50 \%$ of outputs appear in specialist journals (covering, in descending order of publication frequency, the areas of critical studies, education, history, management accounting, auditing, public sector, international and information systems). Of course, papers on these specialist areas appear in generalist journals too, so the implication is that mainstream financial accounting and reporting papers now represent the minority of papers. ${ }^{16}$

In the discipline of finance, there are 196.5 papers spread across 69 journals. Comparing this with accounting, three observations can be made. First, of the papers published in the core disciplines that make up our 'community', about one-third $(32 \%)$ are published in finance journals and two-thirds in accounting journals. Second, if one compares the number of papers with the number of outlets, there appear to be relatively more outlets for finance papers. Third, five of the top eleven ${ }^{17}$ finance journals (in terms of publication frequency) are US based, three have a European perspective, two are UK based (JBFA and Applied Financial Economics), while Journal of Banking and Finance is US based but currently with a European editor. Five of these journals are typically placed highly in ranking studies of finance journals. For example, in Chan et al. (2000), Journal of Finance, Review of Financial Studies, Journal of Money, Credit and Banking, Journal of Banking and Finance and 
Journal of International Money and Finance are ranked $2^{\text {nd }}, 3^{\text {rd }}, 8^{\text {th }}, 10^{\text {th }}$ and $15^{\text {th }}$ respectively. These findings appear to reflect the global nature of financial markets and of finance as an academic discipline.

A summary of the distribution across disciplines is shown in Table 5. A striking statistic is that only half of academic journal publications are located in the core disciplines of accounting and finance. This is all the more remarkable given that the boundaries of the core were broadly set. Accounting and (to a lesser extent) finance can be regarded as applied disciplines, drawing on foundation disciplines such as economics, sociology and psychology.

[Table 5 about here]

The disciplinary distribution of outputs by accounting and finance faculty reveal, perhaps for the first time, the significant extent to which knowledge seems to be fed back to these disciplines. Prior research has focused on information flows into academic accounting and finance. The present study focuses on information flows (represented by publications) out of academic accounting and finance.

The finding that there are significant flows out of accounting and finance contrasts with that of McRae (1974), that the flow of ideas from accounting to other disciplines was negligible. Several non-mutually exclusive explanations exist. First, McRae (1974) examined citations (which are taken to capture 'impact') whereas the present study examines publications (which may not be subsequently cited). Second, it may be that some of the individuals included by the Register as accounting or finance faculty have a different 'home' discipline. For example, given the thin market for finance faculty, some economists have been recruited to accounting and finance departments. It would not be surprising for such individuals to publish economics research in economics journals. Third, it may be that, over the 25 or so years, research in the accounting and finance disciplines has matured and improved sufficiently to justify the publication of applied studies in foundation discipline journals. 
A number of other points can be noted about this table. First, the concentration of outputs within the core disciplines is (as might be expected) far greater for professional outputs than for academic outputs (84\% c.f. $54 \%$ ). Second, management and economics are the two other disciplines in which the accounting and finance community more frequently publishes. Third, the number of outputs in non-Englishlanguage journals is now becoming significant (3\%). There are at least two possible reasons for this: (i) the emergence of research collaborators based in Western continental European countries with refereed non-English journals (Lukka \& Kasanen, 1996); and (ii) interest in the emerging economies of Eastern Europe as a research site, with findings sometimes being reported in both local language journals as well as English-language journals (to ensure that findings are accessible to all interested parties).

\section{Co-authorship}

Patterns of co-authorship across output categories are shown in Table 6. While sole authorship is the norm for professional articles (two-thirds), only just over one-third of academic articles are sole authored. $24 \%$ of academic articles have three or more authors and the average number of authors is almost two (1.93). There are significant differences in co-authorship patterns across the subsets of academic output. For example, $48 \%$ of Top30 A\&F papers are sole authored compared with $25 \%$ for Top30 Oth, giving average numbers of authors of 1.82 and 2.13, respectively. Overall, there is little evidence to suggest that more cooperation is associated with increasing quality of output. ${ }^{18}$ In fact, the average number of authors for Top60 publications (1.89) is almost identical with the average number across all output types (1.87). However, the greater level of co-authorship in Top30 Oth is consistent with a measure of interdisciplinary collaboration. This view is reinforced by the observation that the co-authors in almost all (50 out of 51) of the co-authored Top30 Oth papers are from outside the home department. Interestingly, the average number of authors for coauthored papers of 2.5 is almost identical across all types of output.

[Table 6 about here]

These findings can be compared to those from US studies. Heck et al. (1990) report $50 \%$ co-authorship across 24 accounting journals in 1988 , quite similar to the $52 \%$ for 
Top30 $A \& F$ here. However, the overall figure for academic articles in the present study is $61 \%$, consistent with the general growth in co-authorship that has been documented elsewhere. Hasselback et al. (2000) report an average number of authors of 2.3 in 1993 across 40 accounting journals and a growth rate of 0.017 p.a. This gives a projected estimate of 2.4 authors for 1999, the date of the present study. Our figures for Top30 A\&F and academic articles are 1.82 and 1.93, respectively, which are significantly lower. This suggests that the preference is for smaller author teams in the UK relative to the US. We are currently unable to explain this finding.

A significant minority of co-authorships involve exclusively current colleagues (17.5\% across all outputs), indicating a significant association between these two social links. It is also likely that many of the other co-authorships involve former colleagues, although further research would be required to establish the full extent of this. ${ }^{19}$ The others involve either members of the UK accounting and finance academic community at different institutions (part of the group of 1492 individuals studied in this paper) or individuals outside this community. Separating the contributions made to the total set of outputs in this way reveals that $25 \%$ of contributions involve individuals from outside the community. This group is made up of: UK academics in other disciplines (and normally located in other departments); members of the nonUK accounting and finance academic community, or non-academics. This is a significant proportion and suggests that the UK accounting and finance academic community is reasonably open via interdisciplinary collaboration, collaboration with overseas academics and collaboration with individuals in practice. This is surely a healthy sign.

\section{SUMMARY AND CONCLUSIONS}

This study reports on publishing patterns in the UK and Irish accounting and finance academic community for the two-year period 1998 to 1999 using the data contained in the BAR Research Register. The comprehensive nature of this data supports a detailed analysis of outputs by publication media. The distribution of various types of output (including summary per capita measures) are reported, both for the community as a whole and for key subgroups. There is also an analysis of journal outputs by academic discipline and by individual journal and an analysis of co-authorship 
patterns. These analyses offer insights into the cognitive and social aspects of scholarly knowledge development. Where appropriate, comparisons are made with previous UK studies and with studies in other countries.

It is found that the community has been growing modestly since 1991. The old universities display a significant increase in the proportion of senior staff and this may be attributable to the thin market in the disciplines and the need to offer seniority to attract and retain high quality staff. The proportion of staff with a $\mathrm{PhD}$, though still low relative to the US (where nearly all staff have a PhD) has doubled since 1991 (to $30 \%$ ), while the proportion with a professional qualification has declined from $81 \%$ to 58\%. Prima facie, these shifts are not likely to serve to reduce the gap between research and practice in the profession. The possession of a $\mathrm{PhD}$ seems to be associated with advancement.

Across the whole community, there is a good mix of different forms or output, with nearly half of all outputs in other than academic journals. Professional journal articles account for $16 \%$ of the total and are spread across 92 different outlets. However there is evidence of a substantial decline since 1996. Non-serial publications (such as books and research reports) account for 31\%. The 1,141 distinct academic articles were spread across 442 different journals.

On a per capita basis, giving full credit for co-authorship, the mean number of publications was 1.76 , the figure for faculty at old universities being nearly three times that for faculty at new universities. More senior staff publish more frequently across all main media and possession of a $\mathrm{PhD}$ is associated with a greater volume of academic journal and non-serial outputs. This figure seems to compare favourably with measures for US faculty.

The skewed nature of publishing distributions was also explored. This skew is most in evidence for the lower academic ranks. Interestingly, while professors at old universities tend to publish more 'top 60' academic journal articles than those at new universities, the opposite is true for both 'non-top 60' academic and total output. The 'gap' between the upper and lower ranks is generally much greater in the new university sector. Publication in the top journals is concentrated among staff at the 
old universities - a finding that may underpin the policy of increased specialisation proposed in the recent English Higher Education White Paper.

Significantly more staff are active in publishing in any media compared to 1991 (44\% compared to $35 \%$ ). However, the percentage publishing in the subsets of 'top 60' and 'top 30 accounting and finance' academic journals is relatively low at $17 \%$ and $14 \%$, respectively.

Given that accounting and finance have been argued to be applied disciplines where the flow of ideas tend to be one-way (in rather than out), the disciplinary spread of academic journal publications is significant. Only just over half of all articles are published in the core discipline journals, the rest appearing mainly in management, economics, sociology, education and IT journals. This may indicate a growing maturity in the accounting and finance disciplines, whereby applied research findings are flowing back into related foundation and business disciplines. There is also evidence of a small but significant amount of research being published in non-English language journals.

Nearly two-thirds of academic articles are co-authored, with the average number of authors being 1.93. This seems to be lower that in the US, suggesting a preference for smaller author groups. Interestingly, $25 \%$ of all contributions to all outputs come from outside the community, indicating an openness to interdisciplinary collaboration, collaboration with overseas academics and collaboration with individuals in practice.

The findings of this study will be of assistance to those making career decisions (either their own career or decisions involving other people's careers). They also raise awareness of the way in which the accounting and finance disciplines are developing. The study does, however, have two specific limitations. First, although all journals are included in the analysis, we have formed broad quality groupings, given the pervasive influence of the concept of quality in the discussion of publication activity. These groupings are inherently subjective and contestable, and we make no particular claims regarding the groupings that we use. Second, the analysis covers a period of only two years. While we have no reason to expect that the findings for this 
period are unrepresentative in any way, analysis covering a longer time-frame would confirm this.

We are currently extending this research in a number of directions to investigate issues that require longitudinal data. The relational database has been extended back to 1984 , the date of commencement of the Register. Using this, it will be possible to (i) establish the extent to which co-authorships involve former as well as current colleagues; (ii) determine whether the productivity levels for the two-year period 1998/99 are representative of recent activity levels; and (iii) establish publication performance benchmarks for promotion decisions. Another potentially fruitful area for further research is the nature and extent to which accounting research informs other disciplines. Either a qualitative or quantitative approach could be taken to investigate this issue. For example, the content of the 521 academic articles published by the accounting and finance community in journals outside the core discipline could be systematically reviewed and assessed (albeit subjectively) to establish the extent and nature of interdisciplinary influence. Alternatively, following McRae (1974), one could use citation analysis. 


\section{ENDNOTES}

${ }^{1}$ We do not report an analysis of the data by departments because we feel that it would be insensitive to do so. This inevitably precludes any comparison with the RAE 2001 outcomes. The latter would, in any case, be problematic for two reasons. First, some departments were submitted to the Accounting and Finance panel while others were included as part of a Business and Management submission. In the latter case, the grade awarded to the whole submission may not represent the implicit grade for the accounting and finance sub-group. Second, even the RAE 2001 outcomes for the 20 submissions to Unit of Assessment 44 (Accounting and Finance Panel) cannot meaningfully be compared. The problem lies in dealing with the letter grade dimension of the outcome, which moderates the quality rating. Is a $5 \mathrm{~F}$ better or worse than a $4 \mathrm{~B}$, say?

${ }^{2}$ Cole \& Cole (1967) present evidence that the quality of a scientist's output is more important that quantity in explaining a variety of aspects of reputation (cited in Brown \& Gardner 1985, p.85).

3 The 'new' universities are those created by the abolition of the binary divide together with a few degree-granting colleges.

${ }^{4}$ The Accounting Review (TAR), Journal of Accounting Research (JAR) and Journal of Accounting and Economics (JAE).

${ }^{5}$ Accounting, Organizations and Society (AOS), Accounting and Business Research (ABR), British Accounting Review (BAR) and Journal of Business Finance and Accounting (JBFA).

${ }^{6}$ The list includes 4 non-US journals: Abacus, Accounting and Business Research, Contemporary Accounting Research, and Accounting, Organizations and Society.

${ }^{7}$ To be included, individuals must meet one or more of the following criteria: be located in an accounting and finance department; have a primary commitment to teaching and research in accounting and finance; be a teacher who does the bulk of their teaching on accounting and finance degree courses; or be a researcher who publishes in accounting and finance journals.

${ }^{8}$ A detailed reconciliation is available from the authors upon request.

${ }^{9}$ The groupings formed were as follows:

- professor

- reader

- old universities: reader; associate professor

- new universities: reader; principal lecturer; head of department/school

- senior lecturer - senior lecturer; assistant professor

- lecturer

- other - assistant lecturer; associate lecturer; dean; doctoral fellow; emeritus professor; head of department/school (in old universities); professional tutor; research assistant; research associate; research fellow; senior academic; senior fellow; senior research fellow; senior tutor; teaching assistant; fellow; tutorial fellow; visiting professor, visitor; others.

The US ranks of assistant and associate professor are used primarily by London Business School. In the US, assistant professors normally face the tenure hurdle 6 years after receiving their doctorate, and so might reasonably be considered similar to lecturers in the UK, with associate professors similar to senior lecturers. However, inspection of the records of the individuals involved suggested that they had achieved a higher level of seniority than this.

${ }^{10}$ The following keywords were used: 'student', 'magazine', 'newsletter', and 'news'. In addition, article length was also considered in classifying items, with four pages or less serving to signal a potential professional outlet. It has been noted elsewhere that it is not a simple matter to distinguish refereed from non-refereed journals (Brown \& Gardner, 1985, p.88). 
${ }^{11}$ Reported in Gray \& Helliar (1994, Table 3).

$12134(6.2 \%)$ outputs are included in the database twice (or more) under different institutions. The figures are higher for academic articles than other forms of output.

${ }^{13}$ There are 2,178 unique publications listed in the register after allowing for 134 duplicate publications listed at more than one institution. In total this gives 4,069 possible attributions to individuals, as indicated in the analysis of co-authorship in Table $6(1.87 \times 2,178)$. These attributions fall into three main categories. 1,211 (29.8\%) attributions relate to individuals from outside the UK accounting and finance community (defined by the register as staff in post at 31 December 1999). These individuals may be from other departments in UK institutions, from accounting and finance departments in overseas institutions or may have worked in a UK department of accounting and finance during the two year period but were not in post at 31 December 1999 (e.g. may have moved out of academe, retired or died). A further $5.6 \%$ of attributions were not recorded by co-authors in their home department's entry. $[60 \%$ of these non-recorded items related to non-serial or professional publications, $26 \%$ to non-Top 60 and $14 \%$ to Top60. These non-recordings do not affect Tables 2,5 or 6 , which are based on the total number of unique publications. They have a small impact on Tables 3 and 4 , which relate publications to individuals, mainly affecting lower-level publications by professors. For example, the overall mean number of total publications per member of staff in Table 4 is understated by about 0.16.] This leaves 2,629 attributions by the 1,492 members of staff in the UK academic community at 31 December 1999 , as indicated in Table $3(1.76 \times 1,492)$.

${ }^{14}$ Figure 1 reflects $100 \%$ minus the cumulated data in Table 4.

${ }^{15}$ The editors of Critical Perspectives on Accounting originated from the UK.

${ }^{16}$ We are suggesting here that the relative incidence of mainstream financial accounting papers is declining, although our evidence relates to a single period. This inference is based on the evidence that new journals tend to be specialist journals (Zeff, 1996).

${ }^{17}$ Eleven journals are considered because of a tie in $10^{\text {th }}$ position.

${ }^{18}$ We had no a priori reason to expect that the incidence of co-authorship would be associated with journal quality, though Presser (1980) did find fairly weak evidence of this in relation to the editorial decision on papers submitted to a leading psychology journal.

${ }^{19}$ For example, $4.5 \%$ of the total number of attributions across all output categories relate to co-authors who had worked in the same department during the two year period but who were not in post in that (or any other) UK accounting and finance department at 31 December 1999. 


\section{REFERENCES}

Alexander, J.C. \& Mabry, R.H. (1994). 'Relative significance of journals, authors, and articles cited in financial research', Journal of Finance, 49(2), June, pp. 697-712.

Baxter, W.T. (1988). Accounting Research - Academic Trends versus Practical Needs, Edinburgh, The Institute of Chartered Accountants of Scotland.

Beattie, V.A. \& Ryan, R.J. (1989). 'Performance indices and related measures of journal reputation in accounting', British Accounting Review, 21(3), September, pp. 267-278.

Beattie, V.A. \& Ryan, R.J. (1991). 'The impact of non-serial publications on research in accounting and finance', Abacus, 27(1), pp. 32-49.

Bertin. W.J., Prather, L. \& Zivney, T.L. (1994). 'University library collections of finance periodicals', Financial Practice and Education, 4(2), Fall/Winter, pp. 99-105.

Borgman, C.L. (ed.) (1990). Scholarly Communication and Bibliometrics, Newbury Park, CA, Sage Publications.

Bricker, R.J. \& Previts, G.J. (1990). 'The sociology of accountancy: a study of academic and practice community schisms', Accounting Horizons, 4(1), March, pp.1-14.

Brinn, T., Jones, M.J. \& Pendlebury, M. (1996). 'UK accountants' perceptions of research journal quality', Accounting and Business Research, 26(3), Summer, pp. 265-278.

Brinn, T., Jones, M.J. \& Pendlebury, M. (2001). 'Why do UK accounting and finance academics not publish in top US journals?', British Accounting Review, 33(2), June, pp. 223-232.

Brown, L.D. \& Gardner, J.C. (1985). 'Using citation analysis to assess the impact of journals and articles on contemporary accounting research', Journal of Accounting Research, 23(1), Spring, pp. 84-109.

Brown, L.D., Gardner, J.C. \& Vasarhelyi, M.A. (1987). 'An analysis of the research contributions of Accounting, Organizations and Society, 1976-1984', Accounting, Organizations and Society, 12(2), pp. 193-204.

Brown, L.D. \& Huefner, R.J. (1994). 'The familiarity with and perceived quality of accounting journals: views of senior accounting faculty in leading U.S. MBA programs', Contemporary Accounting Research, 11(1), Summer, pp. 223250 . 
Chan, K.C., Fok, R.C.W. \& Pan, M-S. (2000). 'Citation-based finance journal rankings: an update', Financial Practice and Education, 10(1), Spring/Summer, pp. 132-141.

Cole, S. \& Cole, J.R. (1967). 'Scientific output and recognition: a study in the operation of the reward system in science', American Sociological Review, 32, pp.377-390.

Cottingham, J. \& Hussey, R. (2000). 'Publishing in professional accounting journals: academic institutional performance 1987-96', British Accounting Review, 32(1), March, pp. 101-114.

Cox, E.P., Hamelman, P.W. \& Wilcox, J.B. (1976). 'Relational characteristics of business literature: an interpretative procedure', Journal of Business, 49, April, pp. 252-265.

Durden, C.H., Wilkinson, B.R. \& Wilkinson, K.J. (1999). 'Publishing productivity of Australian accounting 'units' based on current faculty composition', Pacific Accounting Review, 11(1), June, pp. 1-27.

Gee, K.P. \& Gray, R.H. (1989). 'Consistency and stability of UK academic publication output criteria in accounting', British Accounting Review, 21(1), March, pp. 43-54.

Gray, R., Guthrie, J. \& Parker, L. (2002). 'Rites of passage and the self-immolation of academic accounting labour: an essay exploring exclusivity versus mutuality in accounting scholarship', Accounting Forum, 26(1), March, pp. 1-30.

Gray, R.H. \& Helliar, C. (1994). 'UK accounting academics and publication: an exploration of observable variables associated with publication output', British Accounting Review, 26(3), September, pp. 235-254.

Harzing, A-W. (2001), 'Bradford University School of Management journal quality list', University of Bradford [Version: 9 July 2001, downloaded from http://www.harzing.com]

Hasselback, J.R. \& Reinstein, A. (1995). 'A proposal for measuring scholarly productivity of accounting faculty', Issues in Accounting Education, 10(2), pp. 269-306.

Hasselback, J.R., Reinstein, A. \& Schwan, E.S. (2000). 'Benchmarks for evaluating the research productivity of accounting faculty', Journal of Accounting Education, 18(2), pp. 79-97.

Heck, J.L., Jensen, R.E. \& Cooley, P.L. (1990). 'An analysis of contributors to accounting journals. Part I: the aggregate performances', International Journal of Accounting, 25, pp.202-217.

Helliar, C.V. \& Gray, R.H. (2001). British Accounting Review Research Register 2000, ninth edition, London, Academic Press. 
Hickman, K.A. \& Shrader, M.J. (2000). 'Predicting the productivity of new finance professors', Financial Practice and Education, 10(1), Spring/Summer, pp. 93-98.

Hutchinson, C. (1989). 'Consistency and stability of UK academic publication output criteria in accounting: a comment', British Accounting Review, 21(3), September, pp. 279-284.

Lee, T.A. (1989). 'Education, practice and research in accounting: gaps, closed loops and magic accounting', Accounting and Business Research, 19(75), pp.237253.

Lee, T. (1995). 'Shaping the US academic accounting research profession: the American Accounting Association and the social construction of a professional elite', Critical Perspectives on Accounting, 6(3), June, pp. 241261.

Lee, T. (1997). 'The editorial gatekeepers of the accounting academy', Accounting, Auditing \& Accountability Journal, 10(1), pp. 11-30.

Lee, T.A. \& Williams, P.F. (1999). 'Accounting from the inside: legitimizing the accounting academic elite', Critical Perspectives on Accounting, 10(6), December, pp. 867-895.

Locke, J. \& Lowe, A. (2002). 'Problematising the construction of journal quality: an engagement with the mainstream', Accounting Forum, 26(1), March, pp. 4571 .

Lukka, K. \& Kasanen, E. (1996). 'Is accounting a global or a local discipline? Evidence from major research journals', Accounting, Organizations and Society, 21(7/8), pp. 755-773.

McRae, T.W. (1974). 'A citational analysis of the accounting information network', Journal of Accounting Research, 12(1), Spring, pp.80-92.

McRae, T.W., Letza, S.R. \& Sim, G.S.W. (1993). 'A citational analysis of the accounting information network', Paper presented at the British Accounting Association Annual Conference, University of Strathclyde.

Mullins, N.C. (1973). Theories and Theory Groups in Contemporary American Sociology, New York, Harper and Row.

Parker, L., Guthrie, J. \& Gray, R. (1998). 'Accounting and management research: passwords from the gatekeepers', Accounting, Auditing \& Accountability Journal, 11(4), pp. 371-402.

Presser, S. (1980). 'Collaboration and the quality of research', Social Studies of Science, 10, pp. 95-101. 
Puxty, A.G., Sikka, P. \& Willmott, H.C. (1994). 'Systems of surveillance and the silencing of UK academic accounting labour', British Accounting Review, 26(2), pp.137-171.

Read, W.J., Rama, D.V. \& Raghunandan, K. (1998). 'Are publication requirements for accounting faculty promotions still increasing?', Issues in Accounting Education, 13(2), May, pp. 327-339.

Schinski, M., Kugler, A. \& Wick, W. (1998). 'Perceptions of the academic finance profession regarding publishing and the allocation of credit in coauthorship situations', Financial Practice and Education, 8(1), Spring/Summer, pp. 6067.

Tompkins, J.G., Hermanson, H.M. \& Hermanson, D.R. (1996). 'Expectations and resources associated with new finance faculty positions', Financial Practice and Education, 6(1), Spring/Summer, pp. 54-64.

Ulrichs (2001), Ulrich's Periodicals Directory 2001, New Jersey, R.R. Bowker.

Wilkinson, B.R. \& Durden, C.H. (1998). 'A study of accounting faculty publishing productivity in New Zealand' Pacific Accounting Review, 10(2), December, pp. 75-95.

Williams, P.F. \& Rodgers, J.L. (1995). 'The Accounting Review and the production of accounting knowledge', Critical Perspectives on Accounting, 6(3), June, pp. 263-287.

Willmott, H. (1995). 'Managing the academics: commodification and control in the development of university education in the UK', Human Relations, 48(9), September, pp. 993-1027.

Zeff, S.A. (1996). 'A study of academic research journals in accounting', Accounting Horizons, 10(3), September, pp. 158-177.

Zeff, S.A. \& Hofstedt, T.R. (1974). 'The communication gap: the researcher and the practitioner', The Accountant's Magazine, January.

Zivney, T.L. \& Bertin, W.J. (1992). 'Publish or perish: what the competition is really doing', Journal of Finance, 47(1), March, pp. 295-329.

Zivney, T.L., Bertin, W.J. \& Gavin, T.A. (1995). 'A comprehensive examination of accounting faculty publishing', Issues in Accounting Education, 10(1), Spring, pp. 1-25. 


\section{Appendix 1: Decision Rules for Classifying Journals by Discipline}

After a preliminary review of the journal outlets contained in the database to identify the problem areas where classification was unclear, the following decision rules were developed.

\section{Basic categories}

\begin{tabular}{|c|c|c|c|}
\hline Id no & Mnem & Discipline & Other subject keywords \\
\hline 1 & $\mathrm{ACC}$ & Accounting & $\begin{array}{l}\text { Accounting history; accounting education; } \\
\text { management accounting; auditing; accounting } \\
\text { information systems }\end{array}$ \\
\hline 2 & ECON & Economics & Fiscal; political economy; development \\
\hline 3 & FIN & Finance & $\begin{array}{lccc}\text { Corporate finance; } & \text { treasury; } & \text { financial } \\
\text { management; } & \text { markets; institutions } & \text { (banking; } \\
\text { insurance; actuaries); real estate; credit; financial }\end{array}$ \\
\hline 4 & ENG & Engineering & Very few publications so include under 'other' \\
\hline 5 & LAW & Law & Insolvency \\
\hline 6 & MGT & Management & $\begin{array}{l}\text { Business; corporate governance; } \\
\text { relations; admintrial } \\
\text { entrepreneurship; strategy; human resource } \\
\text { management; quality assurance/management; } \\
\text { organisation }\end{array}$ \\
\hline 7 & PSY & Psychology & \\
\hline 8 & $\mathrm{SOC}$ & Sociology/politics/philosophy & Ethics; faith; local government \\
\hline 9 & STAT & Statistics/maths/econometrics & Management science; operational research \\
\hline 10 & TAX & Taxation & Include within core accounting/finance discipline \\
\hline 11 & HIS & History & \\
\hline 12 & EDUC & Education & \\
\hline 13 & OTH & Other & $\begin{array}{l}\text { Physics; tourism; environmental; geography } \\
\text { (places); wine; general sport; voluntary sector; } \\
\text { newspapers (general) }\end{array}$ \\
\hline 14 & DUP & Duplicate pubtype & \\
\hline 15 & MED & Medicine/health & \\
\hline 16 & IT & $\begin{array}{ll}\text { Information } & \text { technology/ } \\
\text { communication } & \end{array}$ & $\begin{array}{l}\text { Computing; information systems; decision } \\
\text { support systems; expert systems [except where } \\
\text { accounting-related see Zeff criteria below] }\end{array}$ \\
\hline 17 & FOR & Foreign language publications & \\
\hline
\end{tabular}

\section{Decision rules}

\section{Accounting and finance publications}

Accounting and finance categories should include all journals that accounting/finance faculty might reasonably be expected to publish in; i.e. the expected 'domain' of the discipline. This recognises that the accounting discipline is essentially derived from many other disciplines. Thus a modified version of Zeff's criteria for recognition of academic research journals in accounting is probably acceptable for our use. This has the benefit of ensuring consistency with his list; all his journals will be subsumed under our accounting and finance list. His criteria were:

'Use of the words Accounting, Auditing, Taxation, Systems (or other accounting-related words) in the journal title, and a significant presence of accounting academics among the editorial staff and among the authors of published articles' (Zeff, 1996, p. 167) 
Our criteria, adjusted to include finance, are:

'Use of the words Accounting, Finance, Auditing, Taxation, Systems (or other accounting/finance-related words) in the journal title, and a significant presence of accounting/finance academics among the editorial staff and among the authors of published articles'

Thus, for accounting and finance publications, the decision depends on the area of application rather than the fundamental discipline; e.g. Accounting Education: the fundamental discipline is education but it is applied in accounting so, based on our criteria, it forms part of the accounting discipline.

NB. Information systems journals were accepted as meeting the 'significant presence of accounting/finance academics' criterion only if $>2$ papers were published therein during the 1998 and 1999 period (i.e. in the Register).

Journals at the interface of accounting 'and' finance are allocated equally: e.g.

Accounting and Finance

$\mathrm{ACC} / \mathrm{FIN}$

\section{Publications outside accounting and finance}

The decision here depends on the fundamental discipline rather than the area of application; e.g. Journal of Nursing Management: the fundamental discipline is 'management' so, even though it is applied in 'medicine', it is deemed to be within the 'management' discipline. Other examples:

\section{Explorations in Economic History HIS \\ International Journal of Economics of Business ECON \\ Legal issues in Business LAW}

We recognise the inconsistency between the decision rules applied to identify publications within and outside accounting and finance. The justification is that our primary focus is to identify publications that would be generally accepted as within/outside the domain of accounting and finance, so a broad definition of 'accounting and finance' is necessary. This requires the inclusion of publications from non-accounting/finance disciplines that are applied within accounting/finance. All other publications will relate to non-accounting/finance applied in nonaccounting/finance areas so our preference is to identify the fundamental discipline rather than the area of application.

'Interface' journals (often signalled by the use of the 'and' operator) that lie wholly outside accounting and finance are allocated equally to their respective disciplines. Maximum of two disciplines: e.g.

Crime Law and Social Change

Current Politics and Economics of Europe

Economic and Social Review

Economy and Society

International Journal of Business and Society
LAW/SOC

$\mathrm{ECON} / \mathrm{SOC}$

$\mathrm{ECON} / \mathrm{SOC}$

$\mathrm{ECON} / \mathrm{SOC}$

$\mathrm{MGT} / \mathrm{SOC}$ 
Results of classification reliability check

\begin{tabular}{|l|c|c|}
\hline & Number & $\mathbf{\%}$ \\
\hline Misclassifications: & & \\
\hline error in applying decision rules & 19 & 3.3 \\
\hline ambiguous title & 19 & 3.3 \\
\hline English/foreign language errors & 6 & 1.0 \\
\hline differences of opinion between researchers & $\underline{6}$ & $\underline{1.0}$ \\
\hline Total misclassifications & 50 & 8.6 \\
\hline Total correct classifications & $\underline{527}$ & $\underline{91.4}$ \\
\hline Total number of journals in database* & $\underline{577}$ & $\underline{100}$ \\
\hline
\end{tabular}

* Some journals in the database had zero entries in the 2000 Register. 


\section{Appendix 2: List of 'Top 60' academic journals}

\section{Accounting/finance core [Top 30 A\&F]}

Abacus

Accounting and Business Research

Accounting Auditing and Accountability $\mathrm{J}$

Accounting Business and Financial History

Accounting Historians J

Accounting Organizations and Society

Accounting Review

Advances in Accounting

Advances in Public Interest Accounting

Auditing: A J of Practice and Theory

Behavioral Research in Accounting

British Accounting Review

Business History

Contemporary Accounting Research

Critical Perspectives on Accounting

Financial Accountability and Management

Financial Analysts Journal

International $\mathrm{J}$ of Accounting

$\mathrm{J}$ of Accounting and Economics

$\mathrm{J}$ of Accounting and Public Policy

$\mathrm{J}$ of Accounting Auditing and Finance

$\mathrm{J}$ of Accounting Literature

$\mathrm{J}$ of Accounting Research

$\mathrm{J}$ of Business Finance and Accounting

$\mathrm{J}$ of Cost Management

$\mathrm{J}$ of Finance

$\mathrm{J}$ of Financial and Quantitative Analysis

$\mathrm{J}$ of International Financial Management and Accounting

$\mathrm{J}$ of Management Accounting Research

Management Accounting Research

Source: Brinn, Jones \& Pendlebury (1996)
Others [Top 30 Oth]

Academy of Management $\mathbf{J}$

Administrative Science Quarterly

British J of Industrial Relations

Business History Review

Decision Support Systems

Economic J

European Economic Review

Human Relations

International J of Public Administration

$\mathrm{J}$ of Banking and Finance

$\mathrm{J}$ of Business

$\mathrm{J}$ of Economic Theory

$\mathrm{J}$ of Empirical Finance

$\mathrm{J}$ of Industrial Economics

$\mathrm{J}$ of International Economics

$\mathrm{J}$ of International Money and Finance

$\mathrm{J}$ of Law and Society

$\mathrm{J}$ of Management Studies

$\mathrm{J}$ of Mathematical Economics

$\mathrm{J}$ of Money Credit and Banking

$\mathrm{J}$ of Public Economics

$\mathrm{J}$ of Social Welfare and Family Law

Management Science

Organization

Organization Studies

Oxford Bulletin of Economics and Statistics

Oxford Economic Papers

Public Administration

Rand J of Economics

Review of Financial Studies

Primary source: Harzing (2001) 


\section{Appendix 3: List of professional journals and number of publications classified by discipline}

Accounting (including taxation) $[\mathrm{n}=37]$

Management Accounting

Accountancy

Student Accountant [was ACCA students newsletter]

CPA J Of Accountancy [Ireland]

Accountancy Ireland

Accounting And Business [was Certified Accountant]

Accounting Technician [AAT]

Account

PASS

Social And Environmental Accounting

Chartered Accountants J Of New Zealand

International Accountant

$\operatorname{Tax} \mathrm{J}$

Accountancy Age

Taxation Practitioner

Certified Diploma Magazine

Company Accountant

Accountancy International

CA Student

European Accounting Focus

Accountability Quarterly

Financial Director

Taxation

Taxes

Accounting Historians Notebook

American Accounting Association - Public Interest

Australian CPA

CA Magazine

CIMA Student

Industry Accounting (China)

Internal Auditing (UK)

Internal Auditor (US)

Perspective [ACCA Hong Kong]

Public Services Accounting Special Group Newsletter

Singapore Accountant

Tolley's Practical Audit And Accounting

Tolley's Practical NIC

Total number of publications

Finance $[\mathbf{n}=\mathbf{1 6}]$

Professional Investor

Financial Times

Financial Times Financial Regulation Report

NGO Finance

Treasurer

Acquisitions Monthly

CIB News

European Fund Manager

Scottish Banker

City Magazine

Eurodeal

Finance

Financial News Briefing Notes

London Stock Exchange News

Risk Magazine

Treasury Management International

Total number of publications

\begin{tabular}{|c|c|}
\hline Management $[n=8]$ & No \\
\hline Henley Manager Update & 8 \\
\hline Chartered Secretary & 5 \\
\hline Benefits And Compensation International & 1 \\
\hline Business Times (Singapore) & 1 \\
\hline Corporate Governance Newsletter & 1 \\
\hline Director & 1 \\
\hline Sewells Automotive Marketing Review & 1 \\
\hline Strategy \& Business & 1 \\
\hline Total number of publications & 19 \\
\hline \multicolumn{2}{|l|}{ Law $[n=5]$} \\
\hline Company Lawyer & 3 \\
\hline Insolvency Bulletin & 2 \\
\hline Anti Laundering And Fraud Alert & 1 \\
\hline Employers' Law & 1 \\
\hline Social Legal Newsletter & 1 \\
\hline Total number of publications & 8 \\
\hline \multicolumn{2}{|l|}{ Sociology/politics/philosophy $[n=4]$} \\
\hline Municipal J & 2 \\
\hline Faith In Business Quarterly & 1 \\
\hline New Review & 1 \\
\hline Stakeholder & 1 \\
\hline Total number of publications & 5 \\
\hline \multicolumn{2}{|l|}{ Education $[n=2]$} \\
\hline Higher Education Equality Unit News & 1 \\
\hline Times Higher Education Supplement & 1 \\
\hline Total number of publications & 2 \\
\hline \multicolumn{2}{|l|}{ Medicine/health $[n=2]$} \\
\hline Health Matters & 1 \\
\hline Practice Manager & 1 \\
\hline Total number of publications & 2 \\
\hline \multicolumn{2}{|l|}{ Other $[n=15]$} \\
\hline Tribune & 3 \\
\hline Edinburgh Evening News & 1 \\
\hline Examiner & 1 \\
\hline Fire Prevention & 1 \\
\hline Irish Independent & 1 \\
\hline Irish Times & 1 \\
\hline Local Environment & 1 \\
\hline RIBA J & 1 \\
\hline Sleaze Report & 1 \\
\hline Soccer Analyst & 1 \\
\hline Sunday Business Post & 1 \\
\hline Sunday Times Business News & 1 \\
\hline The Guardian & 1 \\
\hline The Times & 1 \\
\hline Uniserve Science News & 1 \\
\hline Total number of publications & 17 \\
\hline \multicolumn{2}{|l|}{ Foreign language $[n=3]$} \\
\hline De Operational Auditor (Netherlands) & 1 \\
\hline El Pais & 1 \\
\hline Ucetnictvi & 1 \\
\hline Total number of publications & 3 \\
\hline
\end{tabular}




\title{
Appendix 4: List of academic journals and number of publications classified by discipline
}

Journals at the interface between disciplines (identified in italics) are allocated equally to each discipline. Half the number of papers is listed under each discipline.

\author{
Accounting (including taxation) $[\mathrm{n}=61]$ \\ Critical Perspectives on Accounting \\ European Accounting Review \\ British Accounting Review \\ Accounting Education: an International J \\ $J$ of Business Finance and Accounting \\ Accounting and Business Research \\ Accounting Auditing and Accountability J \\ Management Accounting Research \\ Accounting Organizations and Society \\ Financial Accountability and Management \\ $\mathrm{J}$ of Applied Accounting Research \\ Accounting Business and Financial History \\ Managerial Auditing J \\ International $\mathrm{J}$ of Auditing \\ Irish Accounting Review \\ British Tax Review \\ Accounting Forum \\ Accounting History \\ Irish Tax Review \\ Research in Accounting in Emerging Economies \\ [formerly Research in Third World Accounting] \\ Abacus \\ Institute for the Management of Information Systems J \\ Accounting Historians \\ International $\mathrm{J}$ of Accounting \\ $\mathrm{J}$ of Cost Management \\ Pacific Accounting Review \\ International $\mathrm{J}$ of Accounting and Business Society \\ Issues in Accounting Education \\ Personal Tax Planning Review \\ Advances in International Accounting \\ Advances in Public Interest Accounting
}

Finance $[\mathrm{n}=69]$

$J$ of Business Finance and Accounting

European J of Finance

Applied Financial Economics

European Financial Management

$\mathrm{J}$ of Futures Markets

$\mathrm{J}$ of Banking and Finance

$\mathrm{J}$ of European Financial Services

$\mathrm{J}$ of Finance

$\mathrm{J}$ of Financial Regulation and Compliance

$\mathrm{J}$ of International Money and Finance

Review of Financial Studies

Derivatives Use, Trading and Regulations

European Finance Review

$\mathrm{J}$ of Empirical Finance

Advances in Pacific Basin Financial Markets

Asia-Pacific Financial Markets

British Actuarial J

Credit Control

38 Asia-Pacific J of Accounting

$\mathrm{J}$ of Accounting and Public Policy

$\mathrm{J}$ of Accounting Case Research

$\mathrm{J}$ of International Accounting Auditing and Taxation

$J$ of International Financial Management and Accounting

$\mathrm{J}$ of the Computer Audit Specialist Group of the BCS

Petroleum Accounting and Financial Management $J$

Accounting and Business Review

Accounting Commerce and Finance: the Islamic Perspective J

Accounting Management and Information Technologies

Accounting Management and Insurance Review (Cairo Uni)

Accounting Research J

Advances in Taxation

Artificial Intelligence in Accounting and Auditing

Asia Pacific Accounting Review

Asian Review of Accounting

Asian-Pacific J of Taxation

Contemporary Accounting Research

Eco-management and Auditing

European Taxation

Indian Accounting Review

$\mathrm{J}$ of Accounting Auditing and Finance

$\mathrm{J}$ of Accounting Education

J of Management Accounting Research

$\mathrm{J}$ of New Zealand Taxation Law and Policy

Research in Governmental and Nonprofit Accounting

Research on Accounting Ethics

Review of Accounting Information Systems

Review of Quantitative Finance and Accounting

South African J of Accounting Research

[formerly De Ratione]

Total number of publications

Financial Markets Institutions and Instruments

International $\mathrm{J}$ of Finance and Economics

$\mathrm{J}$ of Corporate Finance

$\mathrm{J}$ of Entrepreneurial and Small Business Finance

$\mathrm{J}$ of Financial and Quantitative Analysis

$\mathrm{J}$ of Fixed Income

$\mathrm{J}$ of Insurance: Mathematics and Economics

$J$ of International Financial Management and Accounting

$\mathrm{J}$ of International Financial Markets, Institutions and Money

$\mathrm{J}$ of Portfolio Management

Managerial Finance

Multinational Finance J

Petroleum Accounting and Financial Management $J$

Public Finance

Review of Derivatives Research

Venture Capital: an International J of Entrepeneurial Finance

Advances in Investment Analysis and Portfolio Management 
Finance (continued)

Applied Mathematical Finance

Bank of England Quarterly Bulletin

Banking and Financial Training

Derivatives Quarterly

European Investment Bank Papers

European J of Financial Services

European Venture Capital J

Financial History Review

Financial Practice and Education

Global Business and Finance Review

International Finance

International J of Finance

International $\mathrm{J}$ of Theoretical and Applied Finance

International Review of Economics and Finance

International Review of Financial Analysis

$\mathrm{J}$ of Credit Management

$\mathrm{J}$ of Derivatives

\section{Management $[\mathbf{n}=\mathbf{1 0 6}]$}

Corporate Governance: an International Review

Public Money and Management

$\mathrm{J}$ of Small Business and Enterprise Development

Organization

$\mathrm{J}$ of Management and Governance

Long Range Planning

British J of Management

Entrepreneurship: Theory and Practice

International J of Public Sector Management

Service Industries J

International J of Bank Marketing

International J of Commerce and Management

International $\mathrm{J}$ of Public Administration

International J of Technology Management

J of Financial Services Marketing

Management

Management Decision

Management Quarterly

Omega

Public Policy and Administration

Academy of Management $\mathrm{J}$

Barcelona Management Review

Control

Cyprus International J of Management

Health Services Management Research

International Association of Management J

International $\mathrm{J}$ of Business Studies

International $\mathrm{J}$ of Contemporary Hospitality Managemen

International J of Entrepreneurial Behavior and Research

International $\mathrm{J}$ of Hospitality Management

International J of Public-private Partnerships

Irish Business and Administrative Research

$\mathrm{J}$ of Business Venturing

No

$\mathrm{J}$ of Entrepreneurial Finance

$\mathrm{J}$ of Financial Information Systems

$\mathrm{J}$ of Financial Intermediation

$\mathrm{J}$ of Financial Management and Analysis

$\mathrm{J}$ of Money Credit and Banking

$\mathrm{J}$ of Property Valuation and Investment

$\mathrm{J}$ of Real Estate Finance and Economics

$\mathrm{J}$ of the Society of Fellows of the Chartered Inst of Insurance

Korean J of Financial Management

Mathematical Finance

Pacific-Basin Finance Journal

Quarterly Review of Economics and Finance

Research in Healthcare Financial Management

Review of Financial Economics

Review of Pacific Basin Financial Markets and Policies

Review of Quantitative Finance and Accounting

Total number of publications

No

$12 \mathrm{~J}$ of Management in Medicine

$2 \mathrm{~J}$ of Management Studies

$\mathrm{J}$ of Product and Brand Management

$\mathrm{J}$ of Small Business Management

Management Learning

6 Managing Service Quality

Middle East Business Review

Nonprofit and Voluntary Sector Marketing

Public Administration

Qualitative Market Research: an International J

Total Quality Management

TQM Magazine

Academy of Management Executive

Administrative Science Quarterly

Advances in International Comparative Management

ASCI J of Management

Australian J of Public Administration

British J of Industrial Relations

Canadian Public Administration

Career Development International

Competition and Change: J of Global Bus \& Polit Economy

Corporate Governance International

Corporate Reputation Review

Employee Relations

European Business J

European Business Review

Executive Business Review

Farm Management

Greener Management International

Human Resource Management J

International J of Arts Management

International $\mathrm{J}$ of Business

International $\mathrm{J}$ of Educational Management
No

1

1

1

1

1

1

1 
Management (continued)

International J of Healthcare Quality Assurance

International J of Healthcare Technology Management

International $\mathrm{J}$ of Management

International $\mathrm{J}$ of Police Science and Managemen

International J of Service Industry Management

International J of Sports Marketing and Sponsorship

International J of Strategic Management

International Rev of Retail Distn and Consumer Research

International Small Business J

Irish Marketing Review

$\mathrm{J}$ of Air Transport Management

$\mathrm{J}$ of Applied Management Studies

$\mathrm{J}$ of Brand Management

$\mathrm{J}$ of Business

$\mathrm{J}$ of General Management

$\mathrm{J}$ of Hospitality and Leisure Marketing

$\mathrm{J}$ of Marketing Management

$\mathrm{J}$ of Nursing Management

$\mathrm{J}$ of Productivity Analysis

$\mathrm{J}$ of Selling \& Major Account Management

$\mathrm{J}$ of Sport Management

Economics $[n=69]$

Economics Letters

Applied Economics Letters

$\mathrm{J}$ of Institutional and Theoretical Economics

$\mathrm{J}$ of Interdisciplinary Economics

$\mathrm{J}$ of Macroeconomics

Manchester School of Economic and Social Studies

Economic J

Ekonomia

$\mathrm{J}$ of Economic Dynamics and Control

$\mathrm{J}$ of International Economics

Agrekon

Annals of Public and Co-operative Economics

Applied Economics

Bulletin for International Fiscal Documentation

Economic Issues

Economics of Transition

$\mathrm{J}$ of Comparative Economics

$\mathrm{J}$ of Development Economics

$\mathrm{J}$ of Economic Behaviour and Organisation

New Economy

Oxford Economic Papers

World Development

Communist Economies and Economic Transformation

Competition and Change: J of Global Bus \& Polit Economy

Economic Inquiry

Economic Notes

Economic Policy

Economic Policy Review

Economic Theory
J of Strategic Change

$\mathrm{J}$ of Travel and Tourism Marketing

Leadership and Organization Development J

Marketing Intelligence and Planning

Optimum: J of Public Sector Management

Personnel Review

Public Administration and Policy [HK \& Asia-Pacific]

Public Management

Quality and Quantity

Quality Assurance in Education

Quality in Higher Education

R\&D Management Journal

Shenshu Business J

Sloan Management Review

Supply Chain Management

Technology Analysis and Strategic Management

Women in Management Review

Entrepreneurship and Regional Development

$J$ of Economics and Business

Total number of publications

Economics of Planning

Economy and Society

Engineering Economis

European Economic Review

Fiscal Studies

Global Economic Review

International Economic J

International J of Economics of Business

International J of Social Economics

International Review of Applied Economics

$\mathrm{J}$ of Economic Development

$\mathrm{J}$ of Economic Integration

$\mathrm{J}$ of Economic Theory

$\mathrm{J}$ of Economics

$\mathrm{J}$ of Evolutionary Economics

$\mathrm{J}$ of Industrial Economics

$\mathrm{J}$ of International Development

$\mathrm{J}$ of Mathematical Economics

$\mathrm{J}$ of Public Economics

$\mathrm{J}$ of Regulatory Economics

New Political Economy

Opec Review

Oxford Review of Economic Policy

Policy Studies

Rand J of Economics

Review of International Economics

Review of World Economics

Scandinavian J of Economics

Small Business Economics 
Economics (continued)

Spanish Economic Review

Sustainable Development

Taiwan J of Political Economy

World Economy

Current Politics and Economics of Europe

Economic and Social Review

Sociology/politics/philosophy $[\mathrm{n}=\mathbf{2 8}$

Business Ethics: A European Review

Parliamentary Affairs

Capital \& Class

$\mathrm{J}$ of Business Ethics

$\mathrm{J}$ of Commonwealth and Comparative Politics

Political Quarterly

Crime Law and Social Change

Economy and Society

Ethics and Society

Faith and Freedom

Human Relations

International $\mathrm{J}$ of the Sociology of Law

J of Law and Society

Local Governance

New Technology, Work and Employment

Philosphical Transactions of the Royal Society

Politics

Regional and Federal Studies

Sociological Review

Talking Politics

Time and Society

Current Politics and Economics of Europe

Economic and Social Review

$J$ of Social Welfare and Family Law

$J$ of the Statistical and Social Inquiry Society of Ireland

$J$ of Transforming Economics and Societies

Social Sciences and Medicine

Third World Quarterly

Total number of publications

Law $[\mathbf{n}=11]$

New Zealand Law J

$\mathrm{J}$ of Business Law

New Law J

Arab J of Administrative Sciences

Business Law Review

Crime Law and Social Change

Environmental Liability

$J$ of Law and Society

Law in Transition

Legal Issues in Business [Curtin Uni]

$J$ of Social Welfare and Family Law

Total number of publications
Entrepreneurship and Regional Development

$J$ of Economics and Business

$J$ of Transforming Economics and Societies

Oxford Bulletin of Economics and Statistics

Third World Quarterly

Total number of publications

8.5

No Education [n $=14]$

Education and Training

$\mathrm{J}$ of Further and Higher Education

$\mathrm{J}$ of Vocational Education and Training

Teaching Business Ethics

Educational Technology

Higher Education

Innovations in Education and Training International

$\mathrm{J}$ of Continuing Professional Development

$\mathrm{J}$ of European Business Education

$\mathrm{J}$ of Graduate Education

$\mathrm{J}$ of Management Development

Perspectives: Policy and Practice in Higher Education

Research in Education

Scandinavian J of Educational Research

Total number of publications

IT/communications [n $=16]$

Information Services and Use

Decision Support Systems

European J of Information Systems

New Review of Applied Expert Systems

British J of Healthcare Computing \& IM

Economic and Financial Computing

European J of Communication

Expert Systems: International J of Knowledge

Engineering and Neural Networks

Information Systems J

Information Technology and People

$\mathrm{J}$ of Information Technology

$\mathrm{J}$ of Logistics and Information Management

No J of Systems and Information Technology [Edith Cowan]

Systemic Practice and Action Research

Systems Practice

J Of Mathematics And Computers In Simulation

Total number of publications 
Statistics/econometrics $[\mathrm{n}=14]$

Cambridge Econometrics

$\mathrm{J}$ of the Operational Research Society

Bulletin of the International Statistical Institute

Communication in Statistics Theory and Methods

IMA J of Mathematics Applied in Business and Industry

$\mathrm{J}$ of Applied Econometrics

Management Science

Mathematical Thought

Statistica Neerlandica

Statistician

Studies in Nonlinear Dynamics and Econometrics

$J$ Of Mathematics And Computers In Simulation

$J$ of the Statistical and Social Inquiry Society of Ireland

Oxford Bulletin of Economics and Statistics

\begin{tabular}{|l|l|}
\hline Total number of publications & $\mathbf{1 8 . 5}$ \\
\hline
\end{tabular}

History $[n=13]$

Business History

Economic History Review

$\mathrm{J}$ of Industrial History

Business History Review

Cheshire History

European Review of Economic History

Explorations in Economic History

History of European Ideas

International $\mathrm{J}$ of Maritime History

International Review of Social History

$\mathrm{J}$ of European Economic History

$\mathrm{J}$ of Transport History

Scottish Economic and Social History

Total number of publications

Other $[\mathbf{n}=16]$

Advances in Concurrent Engineering

Contemporary Wales

European Environment

International J of Modern Physics

$\mathrm{J}$ of Contemporary China

$\mathrm{J}$ of Scientific and Industrial Research

$\mathrm{J}$ of Southern Europe and the Balkans

$\mathrm{J}$ of Sustainable Tourism

J of Transport Geography

$\mathrm{J}$ of Wine Research

Manufacturing Engineer

Prometheus

Regional Studies

Security J

Voluntas

Water International

Total number of publications

17.0

Medicine/health $[\mathbf{n}=8]$

British Medical J

Family Practice

Health and Hygiene

Health and Social Care in the Community

Infusions-therapie

$\mathrm{J}$ of the Royal Society of Health

Lancet

Social Sciences and Medicine

Total number of publications

Psychology [n $=5$ ]

Philosophical Psychology

Humour

Occupational Psychologist

$\mathrm{J}$ of Psychology: Interdisciplinary and Applied

$\mathrm{J}$ of Management Psychology

No Total number of publications

Foreign language $[\mathbf{n}=\mathbf{3 1}]$

Revista Portuguesa de Gestao

Tecnica Contable

Zeszyty Naukowe Akademii Ekonomicznej W Krakowie

Actualidad Financiera

Analisis Financerio

Banca \& Finanzas: Revista Prof de la Gestion Financiera en Esp

Banque et Marches

Bedrifskunde: Tijdschrift voor Modern Management

Bogazici J

Boletin Economico de Ice

Cahiers du Laboratoire de Recherche en Sciences de Gestion Dissonanz

Enterprises et Histoire

Espanola de Financiacion y Contabilidad

No Etika Podnikani a Vereine Spravy

Finanzas Contabilidad

$\mathrm{J}$ of Accounting and Auditing (Finland)

Keizai Seminar

Maandblad voor Accountancy en Bedrifseconomie

New Issues of St Petersburg Univ of Finance \& Economics

Organization Studies

Politi Eka Economie

Revista de Historia Economica

Revista del Instituto Mexincano de Ejecutivos de Finanzas

Revista do Administraccao Contemporanea (Brazil)

Revista do Conselho Regional de Contabilidade

Revista Espanola de Financiacion y Contabilidad

do Rio Grand do Sul

Revue d'Economie Financiere

Revue d'Deconomie Industrielle

Revue d'Economie Politique 
Table 1: Demographic data (\%)

\begin{tabular}{|c|c|c|c|c|c|c|c|}
\hline & \multicolumn{5}{|c|}{ Academic rank ${ }^{1}$} & \multirow[b]{2}{*}{$\begin{array}{c}\text { Total at } \\
\text { Dec } 99\end{array}$} & \multirow[b]{2}{*}{$\begin{array}{l}\text { Total at } \\
\text { Dec } 91^{2}\end{array}$} \\
\hline & Professor & Reader & $\begin{array}{c}\text { Senior } \\
\text { Lecturer }\end{array}$ & Lecturer & Other & & \\
\hline Old universities: & $25[18]$ & $4[2]$ & $16[12]$ & $45[56]$ & $10[12]$ & $\begin{array}{c}100 \\
(n=668)\end{array}$ & $\begin{array}{c}100 \\
(n=599)\end{array}$ \\
\hline \% with $\mathrm{PhD}$ & 70 & 79 & 54 & 45 & 34 & 53 & 32 \\
\hline$\%$ with prof. qual. & 49 & 33 & 53 & 45 & 37 & 46 & 66 \\
\hline New universities: & $5[6]$ & $17[14]$ & $57[60]$ & $15[16]$ & $6[3]$ & $\begin{array}{c}100 \\
(n=824)\end{array}$ & $\begin{array}{c}100 \\
(n=772)\end{array}$ \\
\hline$\%$ with $\mathrm{PhD}$ & 41 & 13 & 9 & 8 & 20 & 12 & 4 \\
\hline \% with prof. qual. & 64 & 70 & 71 & 64 & 47 & 58 & 92 \\
\hline Combined: & $14[11]$ & $11[9]$ & $38[39]$ & $29[34]$ & $8[7]$ & $\begin{array}{c}100 \\
(n=1,492)\end{array}$ & $\begin{array}{c}100 \\
(n=1,371)\end{array}$ \\
\hline$\%$ with $\mathrm{PhD}$ & 64 & 23 & 17 & 34 & 28 & 30 & 16 \\
\hline \% with prof. qual. & 52 & 65 & 68 & 51 & 41 & 58 & 81 \\
\hline
\end{tabular}

Notes:

1. Figures in square brackets are taken from Gray \& Helliar (1994) and relate to December 1991 (8 years prior to the present study).

2. Derived from Gray \& Helliar (1994, Table 3). It has been assumed that faculty do not possess more than one professional qualification. To the extent that they do, the figures will be overstated. 
Table 2: Distribution of total outputs of community across publication media

\begin{tabular}{|c|c|c|}
\hline \multirow[b]{2}{*}{ Publication media } & \multicolumn{2}{|c|}{$\begin{array}{c}\text { Total } \\
\text { population }\end{array}$} \\
\hline & $\begin{array}{l}\text { No. of } \\
\text { items }\end{array}$ & $\%$ \\
\hline Book (non-textbook) & 100 & 4.6 \\
\hline Book chapter & 301 & 13.8 \\
\hline Editor of book & 36 & 1.7 \\
\hline Text book* & 58 & 2.7 \\
\hline Textbook instructors' manual & 11 & 0.5 \\
\hline $\begin{array}{l}\text { Research report for } \\
\text { professional accountancy body }\end{array}$ & 49 & 2.2 \\
\hline Research report for other body & 28 & 1.3 \\
\hline Proceedings & 90 & 4.1 \\
\hline Editorial note & $\underline{9}$ & $\underline{0.4}$ \\
\hline Total non-serial & 682 & 31.3 \\
\hline $\begin{array}{l}\text { Professional journal, including } \\
\text { newspapers }\end{array}$ & 355 & 16.3 \\
\hline Academic journal & 1141 & 52.4 \\
\hline Total & 2178 & 100 \\
\hline
\end{tabular}

* It proved very difficult to distinguish the nature of book publications. Items were classed as books unless we were confident that the item was a textbook. It is likely therefore, that the reported proportion of textbooks is understated and the proportion of books (non-textbook) is overstated. 
Table 3: Per capita number of publications across output categories over 2-year period (full credit for joint publications)

\begin{tabular}{|c|c|c|c|c|c|c|c|c|c|c|c|c|c|c|c|c|c|c|c|c|c|}
\hline \multirow[b]{3}{*}{ Output category } & \multirow{2}{*}{\multicolumn{2}{|c|}{$\begin{array}{c}\text { By } \\
\text { institution } \\
\text { type }\end{array}$}} & \multirow{2}{*}{\multicolumn{5}{|c|}{ By academic rank - old }} & \multirow{2}{*}{\multicolumn{5}{|c|}{ By academic rank - new }} & \multicolumn{4}{|c|}{$\begin{array}{c}\text { By faculty qualification } \\
\text { - old }\end{array}$} & \multicolumn{4}{|c|}{$\begin{array}{c}\text { By faculty qualification } \\
- \text { new }\end{array}$} & \multirow[b]{3}{*}{ Total } \\
\hline & & & & & & & & & & & & & \multicolumn{2}{|c|}{ PhD } & \multicolumn{2}{|c|}{ Prof.qual. } & \multicolumn{2}{|c|}{ PhD } & \multicolumn{2}{|c|}{ Prof.qual. } & \\
\hline & Old & New & Prof & $\mathbf{R}$ & SL & $\mathbf{L}$ & Oth & Prof & $\mathbf{R}$ & SL & $\mathbf{L}$ & Oth & Yes & No & Yes & No & Yes & No & Yes & No & \\
\hline Top30 A\&F & 0.47 & 0.05 & 0.99 & 0.50 & 0.52 & 0.22 & 0.19 & 0.46 & 0.07 & 0.02 & 0.00 & 0.06 & & & 0.51 & 0.42 & & 0.02 & 0.05 & 0.06 & 0.24 \\
\hline Top30 Oth & 0.11 & 0.01 & 0.25 & 0.21 & 0.06 & 0.06 & 0.01 & 0.15 & 0.00 & 0.00 & 0.00 & 0.00 & 0.19 & 0.02 & 0.02 & 0.18 & 0.03 & 0.01 & 0.00 & 0.02 & 0.05 \\
\hline Top60 & 0.57 & 0.06 & 1.24 & 0.71 & 0.58 & 0.28 & 0.20 & 0.62 & 0.07 & 0.03 & 0.00 & 0.06 & 0.72 & 0.41 & 0.53 & 0.60 & 0.28 & 0.03 & 0.05 & 0.08 & 0.29 \\
\hline Non-top60 & 0.98 & 0.37 & 1.66 & 1.29 & 1.07 & 0.71 & 0.33 & 3.15 & 0.48 & 0.17 & 0.06 & 0.53 & 1.19 & 0.75 & 0.92 & 1.04 & 1.19 & 0.26 & 0.27 & 0.58 & 0.64 \\
\hline Total academic journal & 1.55 & 0.43 & 2.91 & 2.00 & 1.64 & 0.99 & 0.53 & 3.77 & 0.55 & 0.19 & 0.06 & 0.59 & 1.91 & 1.16 & 1.45 & 1.64 & 1.46 & 0.29 & 0.31 & 0.66 & 0.93 \\
\hline Professional journal & 0.36 & 0.22 & 0.70 & 0.38 & 0.29 & 0.25 & 0.17 & 1.10 & 0.34 & 0.13 & 0.12 & 0.26 & 0.36 & 0.37 & 0.61 & 0.14 & 0.22 & 0.22 & 0.23 & 0.20 & 0.28 \\
\hline Total non-serial & 0.85 & 0.30 & 1.74 & 0.67 & 0.78 & 0.50 & 0.46 & 2.05 & 0.49 & 0.13 & 0.15 & 0.43 & 1.02 & 0.67 & 0.83 & 0.87 & 0.58 & 0.26 & 0.33 & 0.24 & 0.55 \\
\hline Total & 2.77 & 0.94 & 5.34 & 3.04 & 2.71 & 1.74 & 1.16 & 6.92 & 1.38 & 0.45 & 0.33 & 1.28 & 3.29 & 2.20 & 2.90 & 2.66 & 2.26 & 0.77 & 0.87 & 1.10 & 1.76 \\
\hline
\end{tabular}


Table 4: Frequency distribution (\%) of outputs (full credit for joint publications)

\begin{tabular}{|c|c|c|c|c|c|c|c|c|c|c|c|c|c|c|c|c|c|}
\hline \multirow[b]{3}{*}{ Old universities } & \multirow{3}{*}{ No } & \multicolumn{5}{|c|}{$\begin{array}{c}\text { Panel A } \\
\text { Total outputs }\end{array}$} & \multicolumn{5}{|c|}{$\begin{array}{c}\text { Panel B } \\
\text { Academic journal outputs }\end{array}$} & \multicolumn{3}{|c|}{$\begin{array}{l}\text { Panel C } \\
\text { Top60 }^{2}\end{array}$} & \multicolumn{3}{|c|}{$\begin{array}{c}\text { Panel D } \\
\text { Top30 A\&F }\end{array}$} \\
\hline & & $\overline{0}$ & $1-5$ & 6-10 & $11-15$ & $>15$ & 0 & $1-5$ & 6-10 & $11-15$ & $>15$ & 0 & $1-2$ & $3-6$ & 0 & $1-2$ & $3-6$ \\
\hline & & & & & & & & & & & & & & & & & \\
\hline Professor & 166 & 14.5 & 50.0 & 24.1 & 7.2 & 4.2 & 16.9 & 68.1 & 13.9 & 0.6 & 0.6 & 42.2 & 40.4 & 17.5 & 52.4 & 32.5 & 15.1 \\
\hline Reader & 24 & 8.3 & 79.2 & 12.5 & 0.0 & 0.0 & 25.0 & 70.8 & 4.2 & 0.0 & 0.0 & 58.3 & 29.2 & 12.5 & 70.8 & 20.8 & 8.3 \\
\hline Senior lecturer & 104 & 19.2 & 68.3 & 10.6 & 1.9 & 0.0 & 33.7 & 64.4 & 1.9 & 0.0 & 0.0 & 64.4 & 29.8 & 5.8 & 68.3 & 26.9 & 4.8 \\
\hline Lecturer & 304 & 39.1 & 54.3 & 5.6 & 0.7 & 0.3 & 51.0 & 47.7 & 1.0 & 0.3 & 0.0 & 78.9 & 20.1 & 1.0 & 81.9 & 17.1 & 1.0 \\
\hline Other & 70 & 62.9 & 34.3 & 1.4 & 1.4 & 0.0 & 72.9 & 25.7 & 1.4 & 0.0 & 0.0 & 88.6 & 8.6 & 2.9 & 90.0 & 7.1 & 2.9 \\
\hline Total & 668 & 31.3 & 54.2 & 10.8 & 2.5 & 1.2 & 41.2 & 53.9 & 4.5 & 0.3 & 0.1 & 67.8 & 25.7 & 6.4 & 72.9 & 21.6 & 5.5 \\
\hline New un & & & & & & & & & & & & & & & & & \\
\hline Profe & 39 & 15.4 & 33.3 & 33.3 & 5.1 & 12.8 & 20.5 & 53.8 & 17.9 & 2.6 & 5.2 & 53.8 & 43.6 & 2.6 & 64.1 & 33.3 & 2.6 \\
\hline Reade & 138 & 66.7 & 25.4 & 3.6 & 3.6 & 0.7 & 76.8 & 20.3 & 2.9 & 0.0 & 0.0 & 94.9 & 4.3 & 0.7 & 94.9 & 4.3 & 0.7 \\
\hline Senior & 467 & 81.8 & 16.5 & 1. & 0.2 & 0.0 & 89.3 & 10.3 & 0. & 0.0 & 0.0 & 98.1 & 1.7 & 0.2 & 98.3 & 1.5 & 0.2 \\
\hline Lecturer & 129 & 84.5 & 14.7 & 0.8 & 0.0 & 0.0 & 93.8 & 6.2 & 0.0 & 0.0 & 0.0 & 100.0 & 0.0 & 0.0 & 100.0 & 0.0 & 0.0 \\
\hline Other & 51 & 68.6 & 21.6 & 9.8 & 0.0 & 0.0 & 72.5 & 27.5 & 0.0 & 0.0 & 0.0 & 96.1 & 3.9 & 0.0 & 96.1 & 3.9 & 0.0 \\
\hline Total & 824 & 75.7 & 18.8 & 3.8 & 1.0 & 0.7 & 83.6 & 14.4 & 1.6 & 0.1 & 0.2 & 95.6 & 4.0 & 0.4 & 96.2 & 3.4 & 0.4 \\
\hline Combir & & & & & & & & & & & & & & & & & \\
\hline Professor & 205 & 14.6 & 46.8 & 25.9 & 6.8 & 5.9 & 17.6 & 65.4 & 14.6 & 1.0 & 1.5 & 44.4 & 41.0 & 14.6 & 54.6 & 32.7 & 12.7 \\
\hline Reader & 162 & 58.0 & 33.3 & 4.9 & 3.1 & 0.6 & 69.1 & 27.8 & 3.1 & 0.0 & 0.0 & 89.5 & 8.0 & 2.5 & 91.4 & 6.8 & 1.9 \\
\hline Senior lecturer & 571 & 70.4 & 25.9 & 3.2 & 0.5 & 0.0 & 79.2 & 20.1 & 0.7 & 0.0 & 0.0 & 91.9 & 6.8 & 1.2 & 92.8 & 6.1 & 1.1 \\
\hline Lecturer & 433 & 52.7 & 42.5 & 4.2 & 0.5 & 0.2 & 63.7 & 35.3 & 0.7 & 0.2 & 0.0 & 85.2 & 14.1 & 0.7 & 87.3 & 12.0 & 0.7 \\
\hline Other & 121 & 65.3 & 28.9 & 5.0 & 0.8 & 0.0 & 72.7 & 26.4 & 0.8 & 0.0 & 0.0 & 91.7 & 6.6 & 1.7 & 92.6 & 5.8 & 1.7 \\
\hline Combined total & 1492 & 55.8 & 34.7 & 6.9 & 1.7 & 0.9 & 64.6 & 32.1 & 2.9 & 0.2 & 0.2 & 83.2 & 13.7 & 3.1 & 85.8 & 11.5 & 2.7 \\
\hline
\end{tabular}

\section{Notes}

1. The category 'reader' for new universities is a heterogeneous grouping that includes Principal Lecturers and Heads of Department/School. The publication record of Readers significantly exceeds that of the other individuals in this category.

2. Panels $\mathrm{C}$ and $\mathrm{D}$ are curtailed at 6 outputs as no-one in the community produced more than 6 publications in these categories of output. Indeed, only a very small number of professors at old universities produced more than 4 outputs: just 3(2) professor produced 5(6) Top60 outputs and 2(0) produced 5(6) Top30 A\&F outputs. 
Table 5: Distribution of academic articles across disciplines

\begin{tabular}{|l|r|r|}
\hline \multicolumn{1}{|c|}{ Discipline } & No. of items & \multicolumn{1}{c|}{ \% } \\
\hline Accounting & 399.5 & 35.0 \\
\hline Taxation & 24.0 & 2.1 \\
\hline Finance & $\underline{196.5}$ & 17.2 \\
\hline Sub-total for core discipline & 620.0 & 54.3 \\
\hline Management & 213.0 & 18.7 \\
\hline Economics & 118.5 & 10.4 \\
\hline Sociology/politics/philosophy & 34.5 & 3.0 \\
\hline Education & 20.0 & 1.8 \\
\hline IT/communications & 20.5 & 1.8 \\
\hline Statistics/econometrics & 18.5 & 1.6 \\
\hline History & 17.0 & 1.5 \\
\hline Law & 15.5 & 1.4 \\
\hline Medicine/health & 8.5 & 0.7 \\
\hline Psychology & 5.0 & 0.4 \\
\hline Other & 16.0 & 1.4 \\
\hline Foreign language & 34.0 & 3.0 \\
\hline Total & $\mathbf{1 1 4 1 . 0}$ & $\mathbf{1 0 0}$ \\
\hline
\end{tabular}


Table 6: Patterns of co-authorship

\begin{tabular}{|c|c|c|c|c|c|c|c|c|}
\hline \multirow[b]{3}{*}{ Number of outputs } & \multicolumn{8}{|c|}{ \% of publication outputs } \\
\hline & Top30 A\&F & Top30 Oth & Top60 & Non-top60 & Academic & Professional & Non-serial & Total \\
\hline & 264 & 68 & 332 & 809 & 1141 & 355 & 682 & 2178 \\
\hline \multicolumn{9}{|l|}{ No of authors } \\
\hline 1 & 47.7 & 25.0 & 43.1 & 36.8 & 38.7 & 65.1 & 41.4 & 43.8 \\
\hline 2 & 30.3 & 42.6 & 32.8 & 39.2 & 37.3 & 24.2 & 35.0 & 34.5 \\
\hline 3 & 15.5 & 26.5 & 17.8 & 17.8 & 17.8 & 7.6 & 15.8 & 15.5 \\
\hline 4 & 4.9 & 5.9 & 5.1 & 4.9 & 5.0 & 1.7 & 5.9 & 4.7 \\
\hline$>4$ & 1.5 & 0.0 & 1.2 & 1.2 & 1.2 & 1.4 & 1.9 & 1.5 \\
\hline Total & 100.0 & 100.0 & 100.0 & 100.0 & 100.0 & 100.0 & 100.0 & 100.0 \\
\hline Total \% co-authored & 52.3 & 75.0 & 56.9 & 63.2 & 61.3 & 34.9 & 58.6 & 56.2 \\
\hline Ave no of authors & 1.82 & 2.13 & 1.89 & 1.95 & 1.93 & 1.50 & 1.92 & 1.87 \\
\hline \multicolumn{9}{|l|}{ Co-authored outputs } \\
\hline Number of outputs & 138 & 51 & 189 & 511 & 700 & 124 & 400 & 1224 \\
\hline $\begin{array}{l}\text { Ave no of authors for co- } \\
\text { authored outputs }\end{array}$ & 2.57 & 2.51 & 2.56 & 2.50 & 2.51 & 2.44 & 2.57 & 2.52 \\
\hline $\begin{array}{l}\text { No authored exclusively } \\
\text { intra-department }\end{array}$ & 18 & 1 & 19 & 72 & 91 & 37 & 86 & 214 \\
\hline $\begin{array}{l}\% \text { authored exclusively } \\
\text { intra-department }\end{array}$ & 13.0 & 2.0 & 10.1 & 14.1 & 13.0 & 29.8 & 21.5 & 17.5 \\
\hline
\end{tabular}


Figure 1: Percentage of staff having at least a given number of publications

Panel A: Total publications

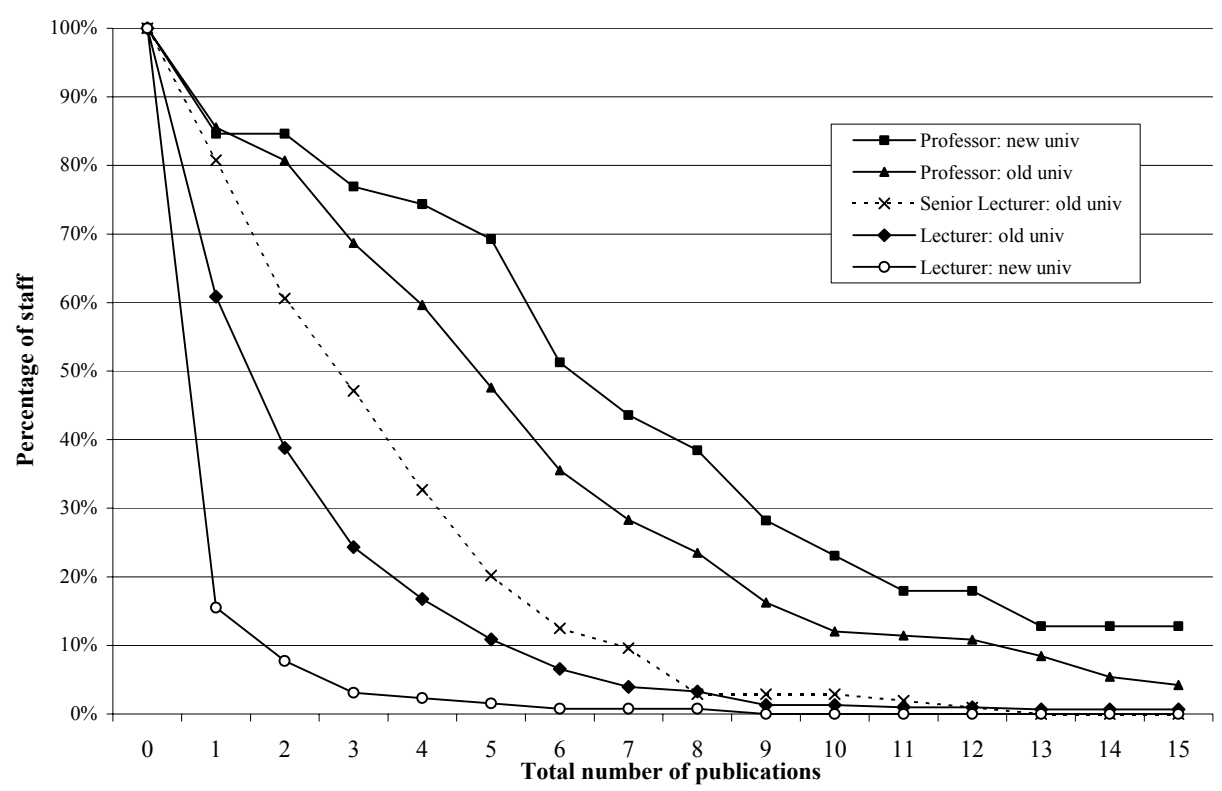

Panel B: Academic publications

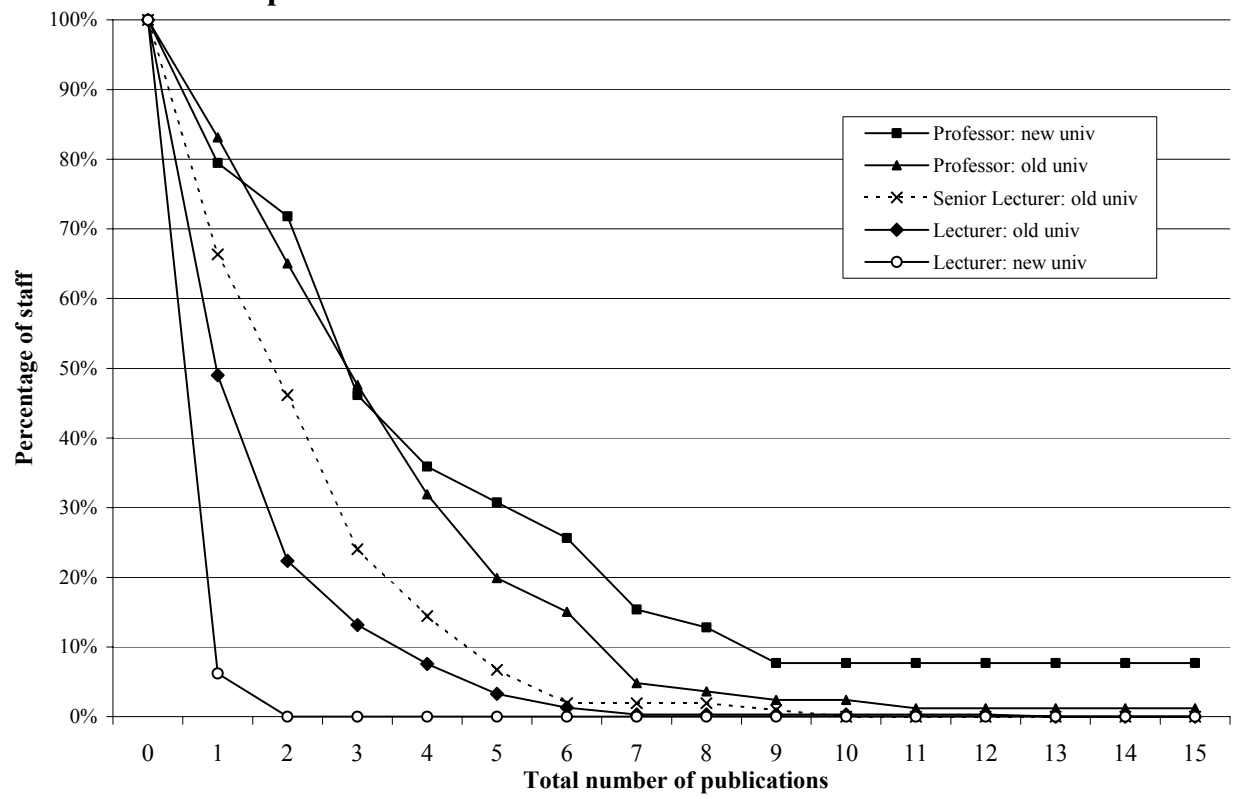

Panel C: Top 60 publications

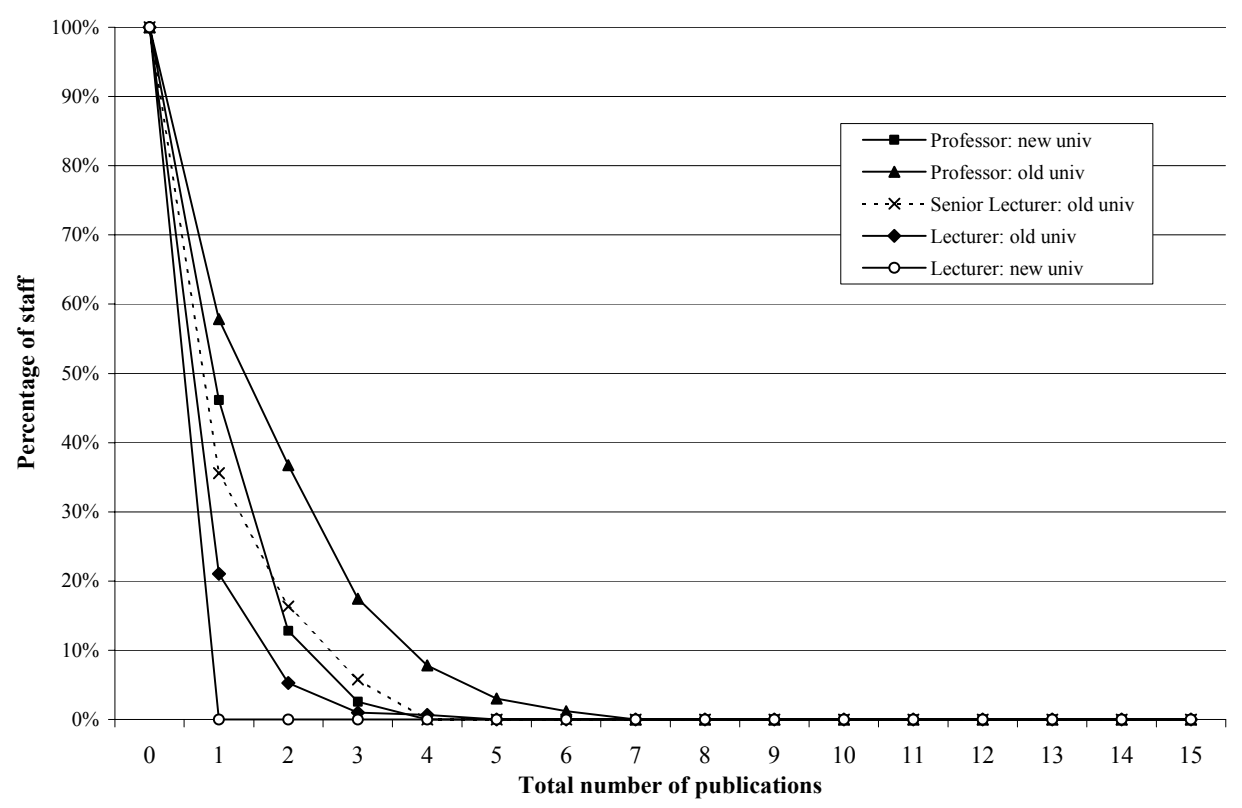

